\title{
The Importance of Catchments to Mine-pit Lakes: Implications for Closure
}

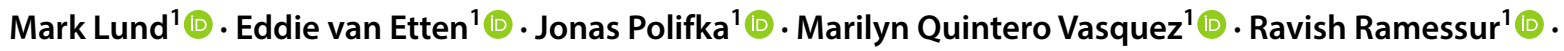 \\ Dechen Yangzom ${ }^{1}$ (D) . Melanie L. Blanchette ${ }^{1}$ (I)
}

Received: 14 April 2020 / Accepted: 10 July 2020 / Published online: 18 July 2020

(C) The Author(s) 2020

\begin{abstract}
Despite the large body of riparian literature for rivers and lakes, there are few studies on the catchments of mine pit lakes. Therefore, the broad objective of this research was to determine if catchment characteristics were related to pit lake nutrient concentrations. We hypothesised that: (1) catchment characteristics would vary among pit lakes, (2) pit lake catchments would differ from co-occurring naturally-forested catchments, and (3) connecting a pit lake (Kepwari) to a naturally-forested catchment via a river flow-through would increase $\mathrm{C}$ accumulation in the lake. The research was conducted in pit lakes of the Collie lake district in Western Australia and examined catchment characteristics (soil nutrients, litter biomass, vegetation, and biomass), carbon and sedimentation rates in pelagic and benthic materials, and establishment of a simple nutrient budget for Lake Kepwari. Broadly, results indicated that catchment vegetation differed significantly among pit lakes (although parts were similar to co-occurring natural forest), with differences largely driven by catchment age. None of the pit lake catchments had true riparian species surrounding the pit lakes. The hypothesis that connecting a pit lake to a watercourse would increase carbon concentrations and sedimentation was not supported. Most (87\%) of the water that entered the lake was from the river, and river outflow was slightly greater than river inflow. However, the lake acted like a nutrient sink, with more $\mathrm{N}$, $\mathrm{P}$, and TOC calculated in the inflows than the outflow. We found that it took 10-15 years of growth for actively rehabilitated pit lake catchments to approximate natural forest and 60 years for unrehabilitated pit lake catchments. Active rehabilitation that includes riparian-specific planting would likely lead to better outcomes for pit lake catchment vegetation. Connecting a pit lake to a river substantially increased catchment size and large amounts of river-derived carbon were deposited in the lake. However, carbon concentrations were relatively low compared to the size of the lake. Our results suggest that active intervention is required if stakeholders are unwilling to wait decades for the biological development of pit lakes.
\end{abstract}

Keywords Carbon $\cdot$ Organic matter $\cdot$ Succession $\cdot$ AMD $\cdot$ Watershed

\section{Introduction}

Electronic supplementary material The online version of this article (https://doi.org/10.1007/s10230-020-00704-8) contains supplementary material, which is available to authorized users.

Melanie L. Blanchette

m.blanchette@ecu.edu.au

Mark Lund

m.lund@ecu.edu.au

1 Mine Water and Environment Research Centre (MiWER), Edith Cowan University, 270 Joondalup Dr, Joondalup, WA 6027, Australia
A lake is a product of its catchment (or 'watershed') (Wetzel 2003). The vegetation of lacustrine catchments typically consists of upland vegetation, riparian vegetation at the water line, and then fringing (or 'littoral') vegetation in the water around the shallow areas of the lake (Naiman and Decamps 1997). Catchments, by definition, provide lakes with water and therefore nutrients $(\mathrm{C}, \mathrm{N}$. and $\mathrm{P})$ that underpin aquatic ecosystems.

Mine-pit lakes (hereafter 'pit' lakes) form in open-cut pits once mining operations have ceased, as the pits are filled by combinations of rainfall, surface runoff, and groundwater. Pit lakes may be considered 'new' lakes subject to the same ecological principles as naturally-formed lakes, with nutrients 
and sediments playing important roles in ecosystem development (Blanchette and Lund 2016). Pit lake catchments are often deliberately minimised to prevent discharges from the lake and to reduce catchment inputs of acidity (Blodau 2006). The sediment in new pit lakes typically consists of the crushed rocks left after mining and is almost completely devoid of organic matter. However, connection of a pit lake to a forested catchment can increase benthic organic matter and potentially promote autochthonous carbon, similar to naturally-formed lakes (Laskov et al. 2002). Over time, benthic organic matter in pit lakes can develop similarly to natural waterbodies, which is likely to be a key part of ecosystem development (Lund and McCullough 2011).

The main sources of allochthonous nutrients for natural lakes in forested catchments are decomposing vegetation and soil (Toming et al. 2013). Leaf litter transport across catchments can be low, with riparian and fringing vegetation potentially accounting for most of the $\mathrm{C}$ entering the stream (Dosskey and Bertsch 1994). Nitrogen fixation occurring in the soils and plant roots may be an important source of $\mathrm{N}$ (Johnson and Turner 2019). Allochthonous nutrients enter the lakes dissolved in water or as particulates via surface, interflow, or groundwater flows (Sepp et al. 2019). Dissolved nutrients are primarily leachate from decomposing vegetation or soils, whilst erosion can liberate particulates of organic and inorganic materials.

Closure and management plans for acidic pit lakes often focus on how to improve water quality by increasing $\mathrm{pH}$. 'Active' chemical treatments, such as liming (Geller and Schultze 2013b), remining (Tucci and Gammons 2015), installation of in-lake bioreactors (Preuss et al. 2007), and whole-lake bioreactors (Geller and Schultze 2013a; McCullough et al. 2008) are potential strategies. Aside from liming and remining, in-lake and whole-lake bioreactors are still unproven approaches to in situ remediation of pit lakes (Geller and Schultze 2013b), and relying on sulfate reduction is unlikely to be effective in weakly acidic low-sulfate lakes (Lund and McCullough 2008).

Examples of pit lakes that have evolved 'passively' from acidic to neutral include those connected to rivers (see McCullough and Schultze 2018), those with emergent rushes (e.g. Lake Knappensee in Germany) (Opitz et al. 2017), and where sulfidic minerals have 'weathered out' and carbon has accumulated (Campbell and Lind 1969; Sienkiewicz and Gąsiorowski 2016). However, many pit lakes do not evolve to become less acidic over time (Kalin and Geller 1998).

The contribution of organic carbon by riparian and catchment vegetation was recognised as a primary causative factor in passive water quality improvements in AMD-affected pit lakes (King et al. 1974). Riparian vegetation facilitates bank stabilisation and the growth of littoral and bank vegetation (van Etten 2011). However, many pit lakes fail to establish riparian or fringing vegetation, even many years after closure, due to a lack of riparian-species specific planting, unstable pit lake margins, low soil nutrient concentrations, and rapidly changing pit lake water levels during filling (van Etten 2011).

Passive acidity neutralisation is more likely to occur in lakes where $\mathrm{C}$ accumulation exceeds $\mathrm{C}$ losses (primarily as $\mathrm{CO}_{2}$ ), thereby overcoming a 'carbon threshold' (Blanchette and Lund 2016). Organic matter as habitat, food, or as a source of nutrients for aquatic organisms can improve aquatic biodiversity even without improvements in water quality, highlighting the importance of catchment connectivity for pit lake remediation (Blanchette et al. 2019; Lund and McCullough 2015). Nitrogen is often not limiting in pit lakes since blasting residues are rich in N (Banks et al. 1997). Co-limitation of $\mathrm{C}$ with $\mathrm{P}$ can occur in lakes due to precipitation and binding of $\mathrm{P}$ to iron and aluminium (Kopácek et al. 2000). This process can constrain both the development of algal biomass (Kumar et al. 2016; Woelfl et al. 2000) and water quality improvement, thereby inhibiting overall pit lake ecological development. In highly acidic pit lakes, organic matter and $\mathrm{P}$ additions can lead to improvements in water quality (Fyson et al. 1998), but $\mathrm{P}$ alone-while increasing algal biomass-may have little impact on lake pH (Fyson et al. 2006). Experimental trials using organic matter and nutrient additions have shown promise in stimulating biological diversity and enhancing water quality in low $\mathrm{pH}$, low acidity lakes (Lund and McCullough 2008, 2009, 2015).

Despite the encouraging results of passive pit lake experiments, low pH, low acidity lakes are unlikely to become circumneutral waterbodies within human timeframes without intervention. One strategy to quickly deliver nutrients and terrestrial plant matter to lakes is to connect a pit lake to a watercourse (McCullough and Schultze 2018). When natural lakes are isolated from watercourses, the catchmentto-lake surface area is relatively small $(\approx 10: 1$; Wetzel 2003). Connection to rivers and streams can dramatically increase a lake's effective catchment size, and rivers and streams contribute biota and plant propagules to lakes (Mitsch et al. 2012). The proportion of the organic matter and sediment that settles in the lake from the river will depend on the lakes 'trapping efficiency', which is related to its hydrology and geomorphology (e.g. Verstraeten and Poesen 2000). The rate at which a river delivers catchment materials to a lake can be assessed by examining the benthic sediment profile (e.g. Blattmann et al. 2019) or by using sediment traps (Bloesch and Burns 1980).

This research builds on data previously published in Lund et al. $(2014,2019)$ investigating the central thesis of Blanchette and Lund (2016) that nutrients (primarily C and P; see Kumar et al. 2016) from catchments are important for pit lake ecosystem development. This study occurred in the Collie pit-lake district in Western Australia (see Lund et al. 2012; Zhao et al. 2009). The broad objective was to determine if catchment characteristics were related to pit lake 
nutrient concentrations. This research was important because catchment rehabilitation is an important aspect of closure, and pit lake catchments can be designed to encourage allochthonous input as part of passive ecosystem development.

Specifically, we compared the soil nutrient concentrations, tree biomass, and litter loads from pit lake catchments of different ages and levels of rehabilitation with literaturederived values for co-occurring natural forest. We assessed the relationship of catchment nutrients to accumulation of nutrients in the lakes by measuring sediment nutrient concentrations. The impact of connecting pit lakes to natural watercourses was determined by assessing carbon sedimentation rates. We hypothesised that: (1) catchment characteristics would vary among pit lakes; (2) pit lake catchments would differ from co-occurring naturally-forested catchments; and (3) connection of a pit lake to a naturally-forested catchment would increase $\mathrm{C}$ accumulation in the pit lakes.

\section{Methods}

\section{Study Sites}

The town of Collie (population $\approx 7500$ ) is located $160 \mathrm{~km}$ south-southeast of the city of Perth and is the centre of coal mining in the Australian state of Western Australia (Fig. 1). Major land uses in the basin are coal mining, timber production, power generation, and agriculture. The Collie coal basin covers an area of $\approx 225 \mathrm{~km}^{2}$ and consists of two sub-basins, the Cardiff sub-basin $\left(151 \mathrm{~km}^{2}\right)$ to the west and the Premier sub-basin $\left(74 \mathrm{~km}^{2}\right)$ to the east, separated partially by a faulted basement high known as the Stockton Ridge (Moncrieff 1993). There are an estimated $6400 \mathrm{Mt}$ of coal resource in the basin, of which economic-demonstrated resources account for $930 \mathrm{Mt}$ (Moody 2017). 'Collie' coal is a sub-bituminous coal with low sulfur content (0.3-0.9\%), and low caking and low ash (4-9\%) properties (Stedman 1988).

Collie is situated in a Mediterranean climate (KoppenGeiger climate type Csa; Perera et al. 2015), with hot, dry summers (range $11.7-30.5^{\circ} \mathrm{C}$ ) and cool, wet winters (range 4.2-16.3 ${ }^{\circ} \mathrm{C}$ ) (Commonwealth of Australia, Bureau of Meteorology (BOM) 18/5/2018). 75\% of the annual rainfall occurs from May to September, and outside these months, evaporation rates exceed rainfall. The 100-year mean annual rainfall for the Collie Basin was $933 \mathrm{~mm}$ (BOM 18/5/2018), although this has decreased to an average of $731 \mathrm{~mm}$ over the last 15 years. Total annual rainfall in Collie between 2004 and 2018 ranged between a minimum of $390 \mathrm{~mm}$ in 2010 and a maximum of $902 \mathrm{~mm}$ in 2005 .

The Collie River has two branches, the main 'eastern' branch and smaller 'southern' branch (hereafter referred to as the 'Collie River South Branch' or CRSB). The CRSB is an intermittently flowing river due to seasonal rain

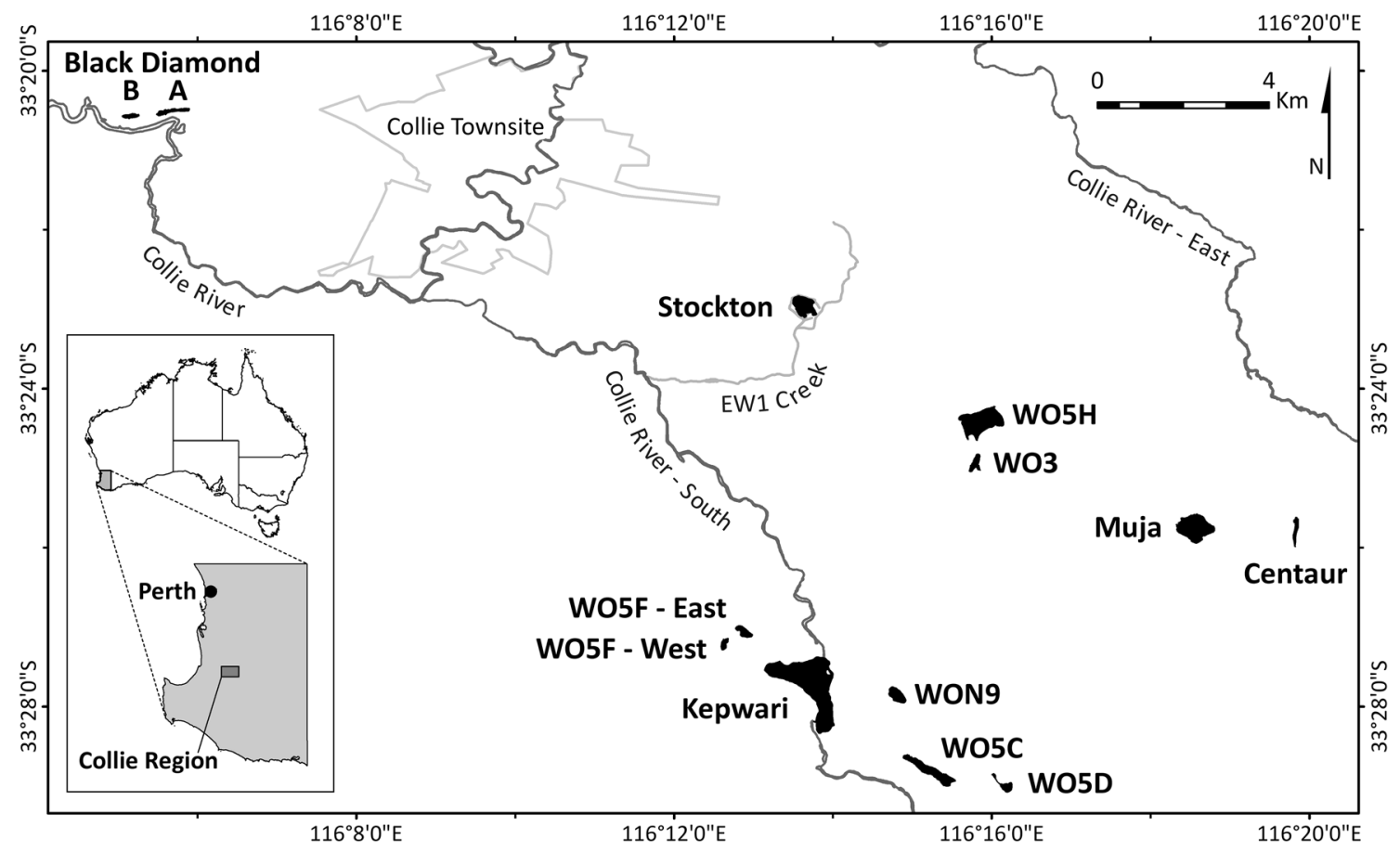

Fig. 1 Map showing location of the Collie region and pit-lake district. Originally published in (Blanchette et al. 2019). Pit lakes sampled as part of this project were: Stockton, WON9, Kepwari, WO5H and
Black Diamond A. 'Collie River-South' is labelled throughout the manuscript as 'CRSB.' Map by Mr. Karl Zwickl 
falls, with total annual flows from 2010 to 2019 averaging $10.7 \times 10^{6} \mathrm{~m}^{3}$ (Dept. of Water and Environmental Regulation, unpublished gauging data). Land clearing for agriculture has caused secondary salinization in the catchment (Cramer and Hobbs 2002; Lymbery et al. 2003), particularly in the Eastern branch, which has degraded overall catchment water quality (Platt et al. 2012). The CRSB has a catchment area of 66,047 ha, which was primarily native jarrah (Eucalyptus marginata) forest with $24 \%$ cleared for farmland and $<5 \%$ disturbed by mining (Harper et al. 2005). Under mining agreements with the state government, companies are mandated to return mined land to jarrah forest, which included reforesting pit lake catchments.

Open-cut coal mining has created a 'district' of 10 pit lakes in the Collie region (Fig. 1). Previous research by the authors demonstrated that the water quality in these pit lakes varied spatially and temporally despite their close proximities (Lund and McCullough 2008; Lund et al. 2012, 2014; Phillips et al. 2000; Zhao et al. 2009). In general, low levels of pyrite oxidation, ferrolysis, and secondary mineralization combined with the low buffering capacity of surrounding rock resulted in the Collie pit lakes tending to have a low $\mathrm{pH}$ and low acidity, with some high metal and metalloid concentrations (Lund et al. 2012; Zhao et al. 2009).

This study sampled five pit lakes: Stockton, WON9, Kepwari, WO5H, and Black Diamond A (hereafter referred to as 'Black Diamond') (Fig. 1). Historical water quality parameters can be found in supplemental Table 1 . All these pit lakes were warm monomictic (mixing typically in June and July) and at the time of the study all had oxic hypolimnions (authors' unpublished data). Additionally, all the lakes consisted of a single basin, with steep sides and limited shallow areas. The largest pit lake sampled was Kepwari (maximum volume is $24 \mathrm{GL}$; maximum depth is $65 \mathrm{~m}$ ), which had the Collie River South Branch (CRSB) diverted around it during mining. The final lake water level was established in 2008 under a rapid-fill program whereby river water was diverted into the mine void during periods of high flow with no discharge from the lake (Salmon et al. 2008). Rapid fill was used to limit acidification of the lake by preventing further oxidation of sulfides in exposed coal seams. Following an accidental river inflow (see McCullough et al. 2012), the state government approved a 3-year trial of connecting the river to the lake as a closure strategy (Lund and Blanchette 2018). During this trial period (2012-2018), water was diverted into the lake via a gate-controlled inlet. The final closure and relinquishment plans involve backfilling the diversion channel and constructing permanent uncontrolled inlet and outlet structures to allow the river to flow unimpeded through the lake. The riparian and catchment areas around Kepwari that were disturbed during mining were contoured for safety and stability and revegetated with upland vegetation in 2002, with some areas revegetated earlier (bathymetry in Müller et al. 2010).

WO5H (volume $11.1 \mathrm{GL}$; maximum depth $81 \mathrm{~m}$ ) was the second-largest Collie pit lake sampled in the study, and bathymetry details can be found in McCullough et al. (2009). WO5H was rapid-filled between 1997 and 2004 with a natural stream composed of mine water surface drainage, dewatering water, and rainfall (Zhao et al. 2009). WO5H is connected to a small stream that is used to manage water runoff from the mine site, including water pumped from operational areas. There is a potential for discharge from WO5H into a natural waterway (linked to EW1); however, the continuous extraction of lake water for power station cooling during the study period prevented discharge and altered water levels by several meters over relatively short periods (weeks). The riparian and adjacent terrestrial areas of WO5H have also been contoured for safety and stability with revegetation using upland taxa during the late 1990s. Planting extended to $2 \mathrm{~m}$ below the final water level to introduce organic matter to the lake (see Blanchette et al. (2019) for effect of planting on ecology of Lake WO5H).

The Stockton pit was abandoned by the mining company and ownership returned to the state of Western Australia in the 1960s without any form of rehabilitation at the time of abandonment. Stockton was managed by the state and used for public camping and water recreation, particularly water skiing. Lake Stockton has had some terrestrial remediation works to reduce risks from spontaneous combustion of coal deposits and highwall collapse. EW1 Creek (Fig. 1) is a natural stream supplemented on occasion by water from Ewington Mine that flows through Lake Stockton. The EW1 creek drains from Stockton into an adjacent swamp and then onwards to eventually join the CRSB (Fig. 1).

The Black Diamond pit was also abandoned and returned to the state of Western Australia in the 1960s without any form of rehabilitation, although, like Stockton, it has spontaneously but slowly regenerated with both native and exotic trees. Black Diamond was owned both by the state and privately, but was not actively managed, although it too has been used for water recreational activities. Black Diamond discharges into the Collie River at high water levels. At the time of the study, the catchment of Black Diamond had revegetated naturally and there were steep (1-4 m) cliffs around much of the shoreline.

Mining in WON9 ceased in 1991 and the lake has not yet reached predicted final water levels (and may never), resulting in 1-2 $\mathrm{m}$ high cliffs along the lake's edge and few littoral areas. Due to its morphology, WON9 cannot discharge surface waters. Like WO5H and Kepwari, the catchment of WON9 has been contoured for safety and stability and 
Table 1 Overview of experimental design, showing replicates, collection times and sites for key aspects of the pit lake sampling field program (Stages 1 and 2)

\begin{tabular}{|c|c|c|c|c|c|c|c|}
\hline & \multirow{3}{*}{$\begin{array}{l}\text { Catchment transects } \\
\text { July } 2012\end{array}$} & \multicolumn{4}{|c|}{ Sedimentation } & \multirow{2}{*}{\multicolumn{2}{|c|}{$\begin{array}{l}\text { Benthic sedi- } \\
\text { ments ( } 3 \text { depths) }\end{array}$}} \\
\hline & & \multicolumn{3}{|c|}{ Center traps (3 depths) } & \multirow{2}{*}{$\begin{array}{l}\text { Edge traps } \\
2018\end{array}$} & & \\
\hline & & Sept. 2016 & Sept./Oct. 2017 & Sept./Oct. 2018 & & 2016 & 2018 \\
\hline Stockton & 3 & & & & & 5 & 5 \\
\hline Black Diamond A & 3 & & & & & 5 & 5 \\
\hline WON9 & 3 & & & & & 5 & 5 \\
\hline Kepwari & 3 & 1 (30 days) & 1 (42 days) & 1 (23 days) & 3 & 5 & 5 \\
\hline WO5H & $\mathrm{n} / \mathrm{a}$ & 1 (30 days) & 1 (42 days) & 1 (23 days) & 3 & 5 & 5 \\
\hline
\end{tabular}

upland vegetation was established throughout the catchment, including riparian areas.

\section{Broad Experimental Design and Rationale}

Stage one of the broad experimental design evaluated how pit lake catchment characteristics (age, degree of rehabilitation) correlated with potential nutrient sources, and the relationship between those sources and lake sediment nutrient concentrations (see Table 1). Four of the five catchments were sampled in July 2012-WO5H was not evaluated as part of stage one. Determination of catchment nutrient sources was assessed through measurement of soil concentrations of $\mathrm{C}, \mathrm{P}$, and $\mathrm{N}$ and litter biomass along transects. Age and measures of rehabilitation such as vegetation communities and tree biomass (density and basal area), litter, and shrub cover were recorded and compared to literaturederived data for co-occurring natural forest.

Stage two sampled Lakes Kepwari and WO5H during 2016, 2017, and 2018 (Table 1). The purpose of stage two was to measure sedimentation rates and the rate of $\mathrm{C}$ accumulation in sediment in pit lakes connected to watercourses. During the period of inflow into the lakes (September and October), sedimentation rates (total and C) were measured in the middle of each lake at multiple depths. Additionally, in 2018, sedimentation rates (total and C) close to the edge of these lakes was measured to evaluate the input of allochthonous material from the adjacent catchment. Benthic sediment data was collected from both lakes from different water depths in 2016 and 2018 to measure $\mathrm{C}$ accumulation in the sediments.

Stage three modelled the magnitude of nutrient inflows and losses for Lake Kepwari over the period 2013-2016. The simple model used river flow and nutrient concentration data (groundwater and river) collected directly from the Lake Kepwari closure trial as well as from the literature. The purpose of stage three was to determine the potential accumulation of nutrients from the Collie River South Branch and local catchment runoff to drive ecosystem development in Kepwari.

\section{Stage 1: Catchment Sampling}

Catchment and lake areas were estimated using Google Earth Pro (Google, USA) in 2012 and revised in 2019 using the polygon tool to trace visible contours and provide an area estimate. The catchment areas were also ground truthed during sampling using visual landmarks.

Pit lake catchments (excluding WO5H) were sampled in July 2012 for vegetation characteristics. The catchments were predominantly covered in jarrah forest, although the unrehabilitated catchments also contained some exotic tree species. Three transects were placed within each catchment perpendicular to the shore and heading upslope at three different localities around the lake to capture as much of any visually-assessed natural variability in vegetation as possible (Kent 2011). Transects were $5 \mathrm{~m}$ wide belts, starting $10 \mathrm{~m}$ into the lake and extending to the top of the catchment to a maximum length of $110 \mathrm{~m}$.

For each transect, each tree rooted within the transect was measured, and terrestrial soil, litter, and sediment samples were collected $(n=$ two samples of each per transect). Trees were identified to species, and their diameter at breast height (DBH) and crown width were measured with a tape measure. The basal area of each tree was calculated for each stem or trunk using the formula $\pi r^{2}$, where applicable (where ' $r$ ' is half the $\mathrm{DBH}$ ). A clinometer was used to measure tree height, and the slope (in degrees) of the ground was measured between trees. A section of the transect $1 \mathrm{~m}$ above and below each tree was visually assessed to determine the percentage cover of ground plants $(<0.3 \mathrm{~m}$ high) and shrubs. Two sites ( $2 \mathrm{~m}$ in length) per transect were established: $5 \mathrm{~m}$ back from the shoreline (hereafter referred to as 'edge') and approximately halfway along the transect ('upslope'). At each edge or upslope site, the representative leaf litter depth (to the soil) was measured with a ruler and the percent of litter cover was visually estimated. Additionally, a $0.25 \mathrm{~m} \times 0.25 \mathrm{~m}$ quadrat was randomly established within each site and all the litter and soil (to $50 \mathrm{~mm}$ ) was collected and stored in clean cotton bags. 
In the aquatic sections of each transect, sediments were collected 5 and $10 \mathrm{~m}$ out from the shore $(\mathrm{n}=$ four benthic sediment samples per transect). SCUBA was used to collect the benthic sediment samples using an acrylic tube, (0.6 (l) $\times 0.12$ (dia.) $\mathrm{m}$ ) to a sediment depth of at least $100 \mathrm{~mm}$. Samples were removed by sealing the tubes top and bottom with rubber bungs and residual water was decanted. The top $10 \mathrm{~mm}$ of sediments (representing the most recent deposits) and then 10-50 mm (longer-term accumulations) were each sliced off from the collected sediment and stored separately in plastic bags. All samples (leaves, soil, sediments) were stored at $\approx 4{ }^{\circ} \mathrm{C}$ using freezer blocks in a cooler (or refrigerator, if overnight) for transport to the laboratory.

On returning to the laboratory, litter, soil, and sediment samples were manually homogenised and then stored at $4{ }^{\circ} \mathrm{C}$ before being oven-dried at $80{ }^{\circ} \mathrm{C}$ to constant weights. Loss on ignition (LOI) was used to assess the percent organic matter in leaf litter and sediments, following burning at $550{ }^{\circ} \mathrm{C}$ for $1 \mathrm{~h}$ to constant weight (Benfield 2007). All soil samples were analysed for organic $\mathrm{C}$, nitrate-N, ammonium-N, P (total and Colwell), sulphur, electrical conductivity (EC), and $\mathrm{pH}\left(\mathrm{CaCl}_{2}\right)$ at CSBP Soil Analysis Laboratories (Perth, Western Australia) as per Rayment and Higginson (1992). Sediment samples were also analysed for total P concentrations at the Edith Cowan University Analytical Facility, as per APHA (2017). Where soil or sediment analysis resulted in values that were below detection, these values were assigned a value of half the detection limit for data analysis.

Tree density, stand basal area, and terrestrial surface litter cover data for co-occurring native forest unimpacted by mining was sourced from Abbott and Loneragan (1986), McCaw (2011), and Stoneman et al. (1997). These values were compared to data collected as part of this study to determine whether there were differences in pit lake vegetation communities compared to natural forest that might affect nutrient availability. The literature values were divided into 'old growth and long unburnt forests', representing high biomass and litter levels and 'regrowth and regularly burnt' (previously logged forests, regenerated, and regularly burnt through a prescribed hazard-reduction burning program) representing most of the jarrah forest in the Collie region.

\section{Stage 2: Sedimentation, Sediment Sampling and Laboratory Processing}

In the centres of WO5H and Kepwari, a single set of sediment traps made of plastic cylinders were deployed for 30 days in Sept. 2016, 42 days in Sept./Oct. 2017, and 23 days in Sept./Oct. 2018 (Table 1). A 'set' of sediment traps (Fig. 2) consisted of groups of 3 cylinders $(0.98 \mathrm{~m}$ long, $80 \mathrm{~mm}$ dia.) sealed at the bottom and attached to a $50 \mathrm{~m}$ rope deployed at depths of 10,25 , and $40 \mathrm{~m}$ representing the top, middle, and bottom of the water column, respectively (Bloesch and Burns 1980). The vertical cylinders were attached $\approx 0.2 \mathrm{~m}$ apart, minimising contamination from any algal growth that might occur on the rope. The $50 \mathrm{~m}$ rope was kept vertical, with a $15 \mathrm{~kg}$ weight at one end, and tensioned by a buoy mounted $2 \mathrm{~m}$ below the water surface, with a second small free-floating buoy used to locate the traps (Fig. 2). Additionally, in 2018, three sets of sediment traps were deployed at equidistant sites around the edges of both lakes (Table 1). However, each set consisted of only a single group of three cylinders mounted at $5 \mathrm{~m}$ depth on a $10 \mathrm{~m}$ rope-otherwise, they were designed and deployed as per the central sediment traps.

At the end of each deployment, all sediment traps were removed from the lakes and each cylinder was immediately capped after collection. Each capped cylinder was manually shaken for at least $20 \mathrm{~s}$ to homogenise any captured sediment, and then a $4 \mathrm{~L}$ aliquot was decanted into storage

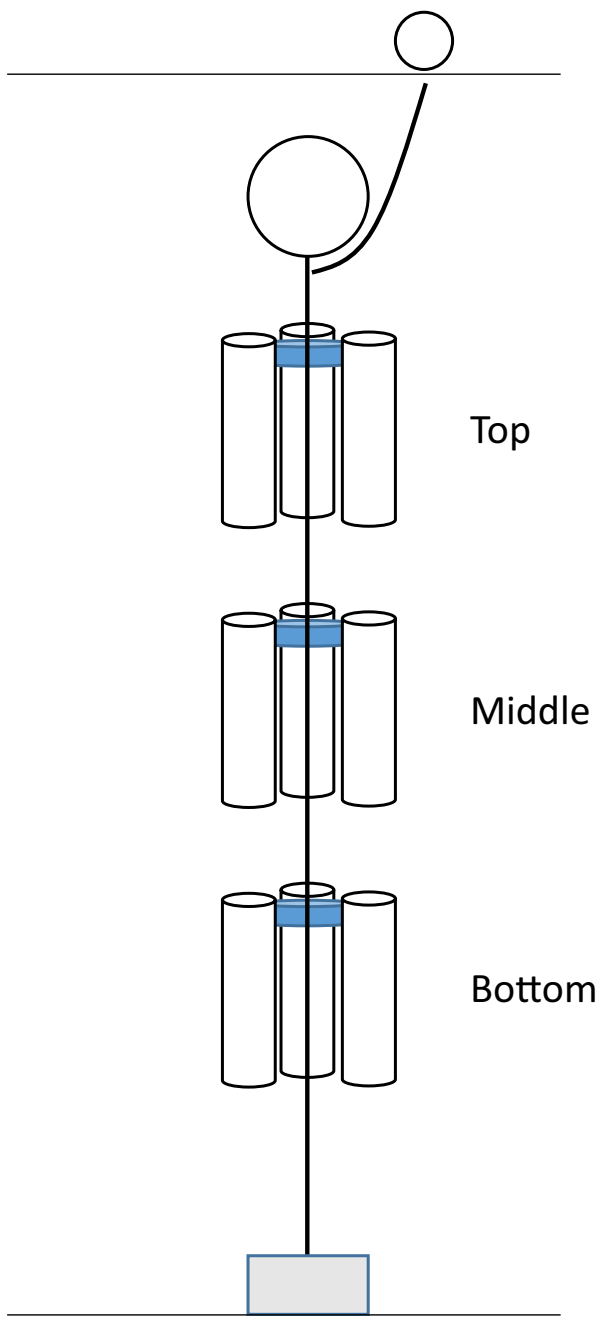

Fig. 2 Diagram of 'centre' sediment traps used to capture pelagic materials in the lakes. Horizontal line shows lake surface, open circles are buoys, open cylinders trap pelagic sediments. Figure first published in Lund et al. (2019) 
containers for transport at ambient temperatures to the laboratory. Samples were stored at $4{ }^{\circ} \mathrm{C}$ for less than $48 \mathrm{~h}$ prior to processing. In the laboratory, duplicates of each sample were filtered under vacuum pressure through $0.5 \mu \mathrm{m}(47 \mathrm{~mm})$ preweighed glass fibre filter paper (Pall Metrigard, USA) until it clogged (85-2455 $\mathrm{mL}$ ) for immediate determination of dry weight (DW) following drying at $80{ }^{\circ} \mathrm{C}$ to constant weight. Dried filters were then burnt for $1 \mathrm{~h}$ at $550{ }^{\circ} \mathrm{C}$ to allow for determination of carbon content via loss on ignition (LOI). Carbon content of the sediment collected from the sediment traps was estimated as half of the LOI value, as per Pribyl (2010).

Five equidistant sites were randomly selected in both Kepwari and WO5H for benthic sediment collection (Table 1). At each site, one sample was collected from each of the following water depths: $<10 \mathrm{~m}$ ('shallow'), 10-20 m ('intermediate'), and $>20 \mathrm{~m}$ ('deep'). Sediment was collected in 2016 using either an Ekman dredge or Peterson sampler (Wildco, Fl, USA) and in 2018 using a Standard Ponar sampler (Wildco, Fl, USA). Sediment samples consisted of $\approx 0.5 \mathrm{~L}$ from the top $100 \mathrm{~mm}$ of sediment, regardless of collection device. In the laboratory, each sediment sample was manually homogenised, and then triplicate subsamples were dried to a constant weight at $60{ }^{\circ} \mathrm{C}$ and then burnt for $1 \mathrm{~h}$ at $550{ }^{\circ} \mathrm{C}$ for determination of LOI.

\section{Stage 3: A Simple Nutrient Budget for Lake Kepwari}

The water budget for Kepwari reported in Lund and Blanchette (2018) and Lund et al. (2018) was simplified into a mean annual model for 2013 to 2016 . Key components of the water budget were the inflows: surface runoff, direct rainfall into the lake, river, and groundwater, and the outflows: river, evaporation, and groundwater. Other components of the water and nutrient budget such as denitrification and interflow (see Grigg 2017), were considered to have a relatively small impact on the nutrient budget and were not investigated further. Data for each water budget component was averaged $(n=4)$ over the time period.

Nutrient data was obtained from Lund and Blanchette (2018) and monitoring data collected by Premier Coal (unpublished) as part of its requirements under the river flow through trial. Nutrient concentrations in surface runoff from the catchment, prior to river connection, at Kepwari were taken from Salmon et al. (2008) and were based on an opportunistic single sample recorded in 2004. Mean nutrient concentration (from all available data $n=18-43$ ) over 2013-2016 for river inflows and outflows was determined.

Groundwater inflow nutrient concentrations were estimated from two nested groundwater bores on the upstream western side of Kepwari sampled by Premier Coal (unpublished data) in Oct. 2015. Mean nutrient concentrations were determined across both bores and screened depths $(n=6)$.
Groundwater outflow out of Kepwari was not measured; however, nutrient concentrations should reflect those of the lake's hypolimnion. Therefore, a mean $(n=11-17)$ of hypolimnetic water samples collected by (Lund and Blanchette 2018) were used to represent groundwater outflow concentrations. No ammonia was measured in the groundwater inflow, but it is typically low relative to $\mathrm{NO}_{3} / \mathrm{NO}_{2}$ (Wetzel 2003).

Total inflow and outflow loads were determined by summing individual component loads of total $\mathrm{P}, \mathrm{N}$, and organic C. However, as total $\mathrm{N}$ and $\mathrm{P}$ are commonly not measured for groundwater, ammonia and $\mathrm{NO}_{3} / \mathrm{NO}_{2}$ loads and groundwater outflow were used for groundwater inflow instead.

Surface runoff export rates were determined for the Kepwari catchment prior to connection to the CRSB and for the CRSB catchment. Export rates were calculated by dividing the relevant nutrient load by the catchment area.

\section{Data Analysis}

The broad approach to data analysis involved use of descriptive statistics, correlations (Pearson), ANOVA, and multivariate analysis using ordination, followed by hypothesis testing using PERMANOVA. Multivariate analysis was undertaken using PRIMER v7 and PERMANOVA + (PRIMER-e, Quest Research Ltd., Auckland, New Zealand) and univariate analysis using SPSS v24 (IBM Corporation, Armonk, NY). Univariate data were transformed $\left(\log _{10}\right.$ or $\left.\log _{10}+1\right)$ as required to achieve homoscedasticity as determined by the Levene's Test. Areas where homoscedasticity was not demonstrated after transformation has been indicated in the results and caution was used in interpretation. Multivariate data was also $\log _{10}$ transformed and normalised prior to determination of resemblance based on Euclidean distance (Clarke and Gorley 2015).

Counts of trees and basal area were scaled to a hectare basis based on the number of trees and total basal area per transect, and the area (length $\times 5 \mathrm{~m}$ ) covered by transects above the water line. Slope, height, shrub, litter, ground cover, and litter depth were averaged across all measurements per transect. Vegetation characteristics were ordinated using principal components analysis (PCO) to ascertain differences among catchments. All vegetation characteristics were then correlated to the ordination space using Pearson's $r$ and shown (where $r>0.6$ ) as vectors on the PCO plot. In multiparameter analysis, if there were only one or two missing values for the parameter (e.g. tree height), then the parameter was retained and the 'Missing' routine in PRIMER (Clarke and Gorley 2015) was used to estimate the missing variable(s); otherwise, the parameter was removed from the analysis. The null hypothesis of no significant difference $(p>0.05)$ among vegetation characteristics from catchments (fixed factor) was tested using a one-way 
PERMANOVA (pseudo-F is reported as Fp; 99999 permutations). Significant differences $(\mathrm{p}<0.05)$ for each vegetation characteristic between catchments were then tested using one-way ANOVA, followed by pairwise comparisons using the Tukey B test. One-way ANOVA was also used to determine significant differences in catchment litter loads across all transects between upslope and edges.

Physico-chemical data (soil concentrations of total $\mathrm{P}$, ammonium, NOx, Colwell $\mathrm{P}$, sulphur, organic $\mathrm{C}$, measures of $\mathrm{EC}$ and $\left.\mathrm{pH}\left(\mathrm{CaCl}_{2}\right)\right)$ were $\log _{10}$ transformed and ordinated in a PCO. All physico-chemical data were then correlated to the ordination space using Pearson's $r$ and shown as vectors on the PCO plot. The null hypothesis of no significant ( $p>0.05)$ difference in physico-chemical data among catchments and location (upslope and edge) was tested using a two-way PERMANOVA with the lake as a fixed factor and location as a random factor in the analysis. Relationships between individual soil parameters were examined by Pearson's $r(\alpha=0.05)$.

The null hypotheses of no significant difference in $\%$ organic matter or total P in sediments between catchments, sediment depth, and distance from the shore (fixed factors) were individually tested in three-way ANOVAs between catchments. In addition, the null hypothesis of no significant difference in \% organic matter in sediments between depths, years, and lakes (Kepwari and WO5H) was tested using three-way ANOVA (fixed factors). Homoscedasticity was not demonstrated, but a $\log _{10}$ transformation reduced heteroscedasticity; however, caution should be used during results interpretation, especially in light of the small sample size (Table 1).

Data (\% organic matter, C, and total dry weight sedimentation rates) from the three cylinders per depth were averaged to determine the characteristics of pelagic sediment at different depths from the sediment traps. Occasionally one cylinder out of the three for a depth would have substantially different values from the other two ( $>50 \%$ different), mainly due the cylinder not hanging vertically in the water column or collecting a clump of material; these results were excluded from the average (Lund et al. 2019). There was no replication of the central sediment traps within lakes (Hulbert 1984), so results at the lake-scale were descriptive only; however, sediment traps around the edge were replicated within lakes ( $\mathrm{n}=3$ per lake) and differences in C sedimentation rate and dry weight of sedimentation were tested individually using one-way ANOVA.

\section{Results}

\section{Stage 1: Catchment Characteristics}

Pit lakes connected to watercourses had greater catchment areas than those not connected to watercourses (Table 2). Black Diamond and WON9 have never been connected to inflowing watercourses and had lake area to catchment area ratios of $<3$. Connection to the CRSB increased Kepwari's lake area to catchment area ratio from 0.5 to 609 . Stockton and $\mathrm{WO} 5 \mathrm{H}$, which were connected to an inflowing watercourse, had a lake area to catchment area ratios of 15.0 and 9.8 , respectively.

Rehabilitated catchments of Kepwari and WON9 were dominated by jarrah (Eucalyptus marginata), and 'marri' (Corymbia calophylla) forests. In contrast, the naturally regenerated catchments of Stockton and Black Diamond contained more exotic species, such as pine and 'spotted gum' (Corymbia maculata), although they were still dominated by native jarrah and marri trees. There was no true riparian vegetation recorded in any of the catchments, although fringing emergent taxa such as rushes were present around Stockton and Black Diamond A (both $<20 \%$ of the lake edge) and Lake Kepwari (a few patches). The presence of fringing vegetation in Lake Kepwari was likely due to entry of propagules during the river breach in 2011 and later flow-through trial (see Jones et al. 2020).

A one-way PERMANOVA indicated that vegetation characteristics were significantly $(\mathrm{Fp}=2.48, \mathrm{P}=0.041)$ different among pit lake catchments. In the ordination space, Lake WON9 separated from the rest of the catchments along PCO axis 2, and relative to other catchments, WON9 had overall less variability among transects (Fig. 3). Lake Kepwari transects varied along axis 2 rather than axis 1, and Black Diamond and Stockton Lake transects varied along both axis 1 and 2 (Fig. 3). Separation of catchment variables on PCO
Table 2 Estimated size of the pit lakes and catchments in Collie, Western Australia (unconnected, catchment area without

watercourse catchments; connected, catchment with watercourse catchment included)

\begin{tabular}{|c|c|c|c|c|c|}
\hline \multirow[t]{2}{*}{ Lake } & \multirow[t]{2}{*}{ Lake area (ha) } & \multicolumn{2}{|c|}{ Catchment area $(\mathrm{ha})^{\mathrm{a}}$} & \multicolumn{2}{|c|}{ Lake area: catchment area } \\
\hline & & Unconnected & Connected & Unconnected & Connected \\
\hline Stockton & 15.4 & - & 231.6 & - & 15.0 \\
\hline Black Diamond & 4.9 & 10.1 & - & 2.1 & - \\
\hline WON9 & 7.8 & 23.5 & - & 3.0 & - \\
\hline Kepwari & 98.5 & 50.3 & 60,000 & 0.5 & 609 \\
\hline WO5H & 38.1 & - & 411 & - & 9.8 \\
\hline
\end{tabular}

${ }^{\text {a}}$ Excludes lake area 
axis $1(53.2 \%)$ was driven by ground cover, crown width, slope, and shrub cover (Fig. 3). Measures of tree biomass (height, basal area, and number of trees) and litter biomass (cover and depth) were important along the PCO axis 2 (27.3\%), which were the lowest in Lake WON9.

Ordination of catchment data showing how Lakes WON9 and Kepwari were different from the rest of the catchments was supported by the results of one-way ANOVAs (Supplemental Table 1). Lake WON9 had significantly $\left(\mathrm{F}_{3,8}=11.93\right.$; $\mathrm{P}=0.003$ ) less ground cover (mean $0.4 \pm 0.1 \%$ vs $4.4-15.2 \%$ other catchments) and lower stand basal area $\left(\mathrm{F}_{3,8}=15.37\right.$; $\mathrm{P}=0.001$; mean 0.3 vs $10.2-122.4 \mathrm{~m}^{2} \mathrm{ha}^{-1}$ ) than Black Diamond, Stockton, and Kepwari. Tree heights were also lower in WON9 compared to the other lakes and smaller tree heights (2.3 m compared to 5.5-8.4 m). Shrub cover was significantly $\left(\mathrm{F}_{3,8}=4.70 ; \mathrm{P}=0.036\right)$ different between catchments, with the highest at Lake Kepwari (31.9\%) and lowest in Black Diamond (4.0\%). However, there were no significant differences among lakes for tree density, crown width, litter cover, litter depth, and slope (Supplemental Table 2).

Old-growth jarrah forest had 200-500 trees ha ${ }^{-1}$, with average forest basal areas of 30-50 $\mathrm{m}^{2} \mathrm{ha}^{-1}$ and $15-25 \mathrm{t}$ $\mathrm{ha}^{-1}$ of leaf litter, whereas regrowth (burned) jarrah forest had more trees per hectare (500-1000) that were smaller in size (20-30 $\left.\mathrm{m}^{2} \mathrm{ha}^{-1}\right)$ and produced less surface litter (5-10 $\mathrm{t} \mathrm{ha}^{-1}$ ) (Table 3; Abbott and Loneragan 1986; McCaw 2011; Stoneman et al. 1997). With respect to number of trees, study catchments were similar to co-occurring unmined jarrah forests (Table 3). However, mean stand basal area was generally about half that of unmined jarrah forest although it was higher at Stockton Lake $\left(122.4 \mathrm{~m}^{2} \mathrm{ha}^{-1}\right.$ on average, although highly variable) and Lake WON9 was lower (average of $0.3 \mathrm{~m}^{2} \mathrm{ha}^{-1}$ ) (Table 3). In all catchments, leaf litter was significantly higher in upslope than edge areas $\left(F_{1,20}=8.64, p=0.008\right.$; Table 3$)$. Surface litter loads at edges tended to be less than those in co-occurring unmined forest, whereas upslope areas were more like litter loads in unmined forests (Table 3).

Soil physico-chemistry was significantly different between 'edge' and 'upslope' $(\mathrm{Fp}=5.03 ; \mathrm{P}=0.003$, no significant interaction; $\mathrm{Ps}=1.57 ; \mathrm{P}=0.12$ ), but not among catchments $(\mathrm{Fp}=1.38 ; \mathrm{P}=0.34)$. In the ordination space, soil physico-chemistry was driven by $\mathrm{pH}\left(\mathrm{CaCl}_{2}\right)$ and ammonium on PCO axis 1 (53.5\%), and soils with higher $\mathrm{pH}$ levels tended to co-occur with lower levels of organic C (Fig. 4). Upslope soils on PCO axis 2 (28.2\%) tended to have higher $\mathrm{P}$ concentrations (total and Colwell) and concentrations of organic $\mathrm{C}$ than edge soils, which in turn tended to have higher EC and pH (Fig. 4; Supplemental Table 3). High nutrient concentrations in upslope areas co-occur with higher litter biomass found upslope. However, litter biomass did not appear to strongly influence the soil beneath it, with only a weak correlation $(\mathrm{r}=0.48, \mathrm{P}<0.05)$ to organic $\mathrm{C}$, and none to any other measured parameter. Soil nutrients (total $\mathrm{P}$, organic $\mathrm{C}$, Colwell $\mathrm{P}$, sulphur, ammonia, nitrate) were all weakly correlated $(r>0.36 ; \mathrm{P}<0.05)$ with each other. The source of nutrients in the soils could not be determined from the data. Soil parameters of rehabilitated and
Fig. 3 Principle coordinates analysis of pit lake vegetation characteristics with an overlay of catchment, showing Pearson correlations (circle represents $r=1$ ) vectors for characteristics

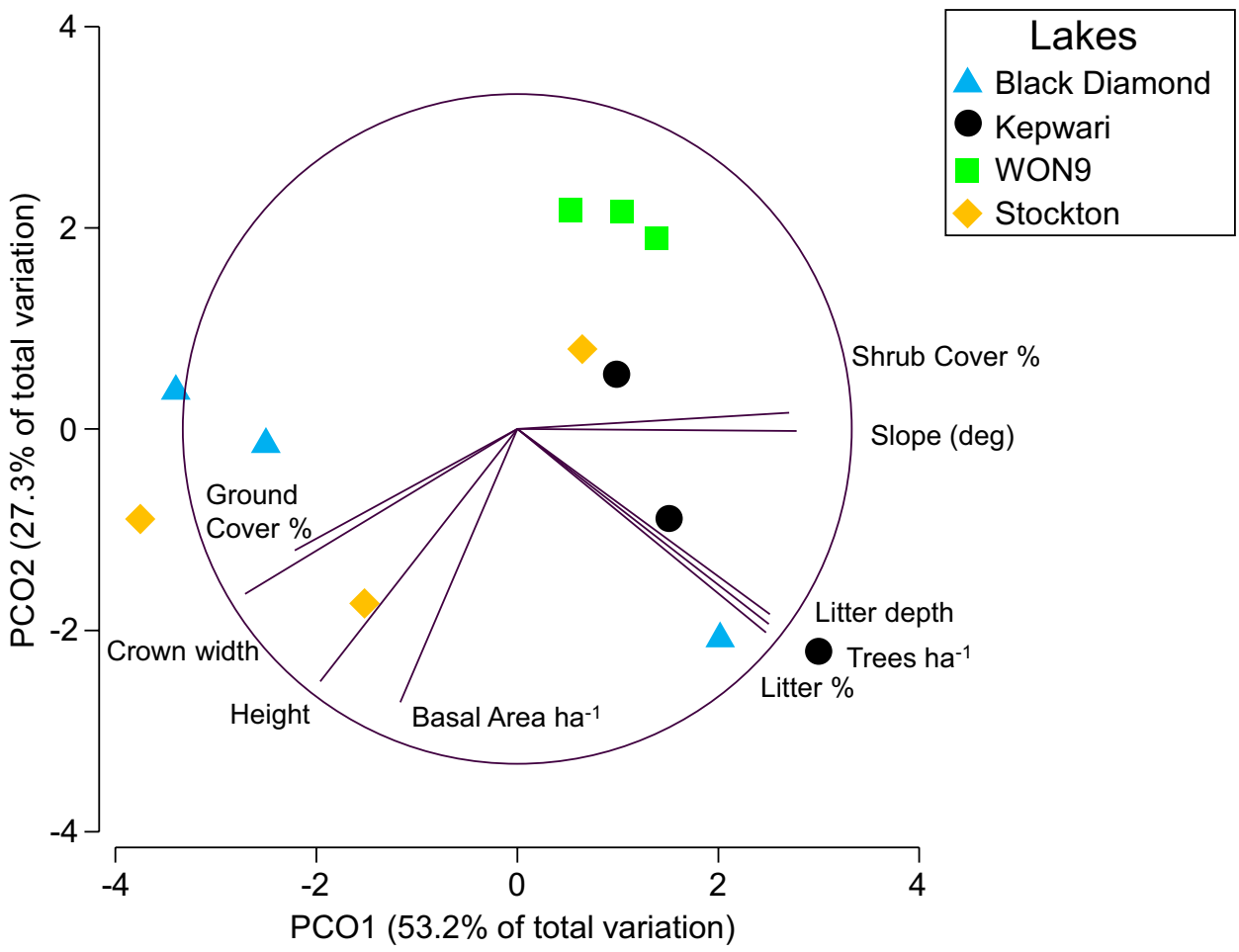


Table 3 Mean $(n=3$; unless indicated otherwise) tree density, basal area $( \pm$ SE) and surface litter coverage for pit lake catchments compared to natural old-growth and regrowth jarrah forest in Collie, Western Australia

\begin{tabular}{|c|c|c|c|c|}
\hline \multirow[t]{2}{*}{ Lake } & \multirow{2}{*}{$\begin{array}{l}\text { Tree Density } \\
\text { trees } \mathrm{ha}^{-1}\end{array}$} & \multirow{2}{*}{$\begin{array}{l}\text { Tree Basal } \\
\text { Area } \\
\mathrm{m}^{2} \mathrm{ha}^{-1}\end{array}$} & \multicolumn{2}{|c|}{ Surface Litter } \\
\hline & & & $\begin{array}{l}\text { Edge } \\
\mathrm{tha}^{-1}\end{array}$ & $\begin{array}{l}\text { Upslope } \\
\text { t ha }^{-1}\end{array}$ \\
\hline Stockton & $253 \pm 63$ & $122.4 \pm 77.9$ & $0.14 \pm 0.04$ & $3.0(n=2)$ \\
\hline $\begin{array}{l}\text { Black dia- } \\
\text { mond }\end{array}$ & $648 \pm 368$ & $12.5 \pm 3.2$ & $11.0 \pm 10.2$ & $6.1 \pm 4.4$ \\
\hline WON9 & $166 \pm 23$ & $0.3 \pm 0.04$ & $0.4(\mathrm{n}=2)$ & $2.8 \pm 1.4$ \\
\hline Kepwari & $850 \pm 364$ & $10.2 \pm 4.6$ & $0.4 \pm 0.06$ & $15.8 \pm 2.7$ \\
\hline $\begin{array}{l}\text { Old-growth } \\
\text { and long } \\
\text { unburnt jar- } \\
\text { rah forest }^{\mathrm{a}}\end{array}$ & $200-500$ & $30-50$ & $15-25$ & \\
\hline $\begin{array}{l}\text { Regrowth } \\
\text { and } \\
\text { prescribed } \\
\text { burned jar- } \\
\text { rah forest }\end{array}$ & $500-1000$ & $20-30$ & $5-10$ & \\
\hline
\end{tabular}

${ }^{\text {a }}$ Data based on McCaw (2011), Abbott and Loneragan (1986) and Stoneman et al. (1997)

non-rehabilitated catchments mostly fell within the broad range of values reported from mature native jarrah forest from the region (Supplemental Table 2). The main exception was sulphur, which was greater in the studied catchment topsoils than in the native forests.

Two three-way ANOVAs were run on 48 measurements of percent organic matter and total $\mathrm{P}$ concentrations in sediments from Black Diamond, Stockton, WON9, and Kepwari to examine the effects of sediment depth (0-10 $\mathrm{mm}$ or $10-50 \mathrm{~mm})$, distance from the shore (5 or $10 \mathrm{~m}$ ), or catchment (lake). There were no significant differences in percent organic matter (LOI) or total $\mathrm{P}$ concentration in benthic sediments by sediment depth (total $\mathrm{P} \mathrm{F}_{1,32}=0.591, \mathrm{P}=0.583$; LOI $\mathrm{F}_{1,32}=10.417$, $\mathrm{P}=0.191$ ), catchment (total $\mathrm{P} \mathrm{F}_{3,32}=0.118, \mathrm{P}=0.943$; LOI $\left.\mathrm{F}_{3,32}=1.307, \mathrm{P}=0.416\right)$, or distance from shore (5 and $10 \mathrm{~m}$ ) (total $\mathrm{P}_{1,32}=0.428, \mathrm{P}=0.558$; LOI $\left.\mathrm{F}_{1,32}=1.647, \mathrm{P}=0.287\right)$. Homoscedasticity for total $\mathrm{P}$ data was not achieved after transformation. Mean total $\mathrm{P}$ concentrations were $32.4 \pm 3.3 \mathrm{mg} \mathrm{kg}^{-1}$ and $5.19 \pm 0.6 \%$ for organic matter (across both depths and distances and all catchments, $n=48)$.

\section{Stage 2: Sediments and Sedimentation in Lakes Kepwari and W05H}

A three-way ANOVA was run on a sample of 72 measurements of percent organic matter in sediments from Lake Kepwari and WO5H to examine the effects of sample depth ( $<10 \mathrm{~m}, 10-20 \mathrm{~m},>20 \mathrm{~m})$, collection year $(2016,2018)$ or lake. There was no significant difference between the lakes $\left(\mathrm{F}_{1,48}=0.300, \mathrm{P}=0.587\right)$ but significant differences were found between sample depth $\left(\mathrm{F}_{2,48}=22.513, \mathrm{P}=0.000\right)$ and year $\left(\mathrm{F}_{1,48}=10.338, \mathrm{P}=0.002\right)$. However, homoscedasticity was not achieved after transformation and the year and sample depth interaction was significant $\left(\mathrm{F}_{2,48}=8.558\right.$, $\mathrm{P}=0.001)$. Marginal means for depth and lake show that the interaction occurred as percent organic matter in sediment from deep sites decreased slightly between years, increased in the shallow sites and did not change in the intermediate zone. Percent organic matter percent generally increased in
Fig. 4 Principle coordinates analysis of soil physico-chemical characteristics with an overlay of catchment and location, showing Pearson correlations vectors (circle represents $r=1$ ) for measured variables. Locations were 'edge' (sampled in transect within $5 \mathrm{~m}$ of the lake edge) and 'upslope' (in transect approximating the middle of the catchment)

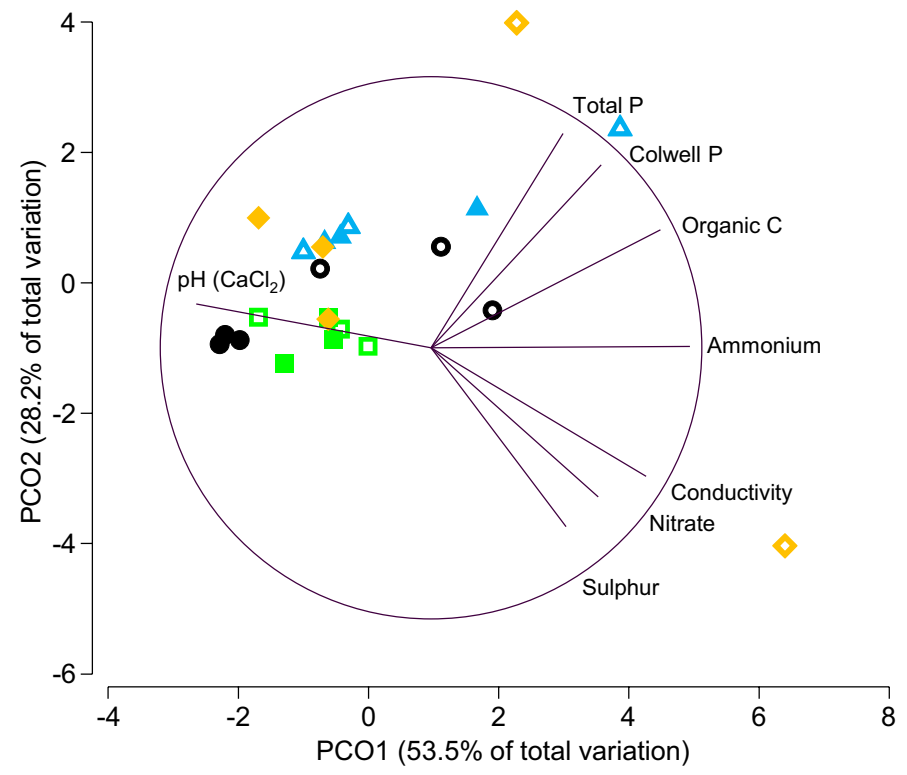


Table 4 Mean $( \pm$ SE) concentrations of nutrients and estimated loads $(\mathrm{kg})$ from 2013 to 2016 for key water inputs and outputs from Lake Kepwari, Western Australia (data sources indicated by letters, figures in brackets are provided for reference and not used for load calculations)

\begin{tabular}{|c|c|c|c|c|c|c|c|}
\hline Water source & $\begin{array}{l}\text { Volume } \\
\text { ML }\end{array}$ & $\begin{array}{l}\mathrm{NH}_{4} \\
\mu \mathrm{g} \mathrm{L}^{-1}\end{array}$ & $\begin{array}{l}\mathrm{NO}_{3} / \mathrm{NO}_{2} \\
\mu \mathrm{g} \mathrm{L}^{-1}\end{array}$ & $\begin{array}{l}\text { Total N } \\
\mu \mathrm{g} \mathrm{L}^{-1}\end{array}$ & $\begin{array}{l}\text { FRP } \\
\mu \mathrm{g} \mathrm{L}^{-1}\end{array}$ & $\begin{array}{l}\text { Total P } \\
\mu g \mathrm{~L}^{-1}\end{array}$ & $\begin{array}{l}\text { TOC } \\
\mathrm{mg} \mathrm{L}^{-1}\end{array}$ \\
\hline Direct rainfall & $765 \pm 95^{\mathrm{b}}$ & & & $\begin{array}{l}268^{\mathrm{g}} \\
205 \mathrm{~kg}\end{array}$ & & $\begin{array}{l}21^{\mathrm{g}} \\
16 \mathrm{~kg}\end{array}$ & \\
\hline Surface runoff & $\begin{array}{l}103.3 \pm 11.8^{\mathrm{b}} \\
\left(50^{\mathrm{a}}\right) \\
\mathrm{n}=4\end{array}$ & $135^{\mathrm{a}}$ & $21^{\mathrm{a}}$ & $\begin{array}{l}1700^{\mathrm{a}} \\
176 \mathrm{~kg}\end{array}$ & $<2^{\mathrm{a}}$ & $\begin{array}{l}255^{\mathrm{a}} \\
27 \mathrm{~kg}\end{array}$ & $\begin{array}{l}4.2^{\mathrm{a}} \\
217 \mathrm{~kg}\end{array}$ \\
\hline River inflow & $\begin{array}{l}7244 \pm 2444^{b} \\
n=4\end{array}$ & $\begin{array}{l}82 \pm 28 \mathrm{e} \\
\mathrm{n}=18\end{array}$ & $\begin{array}{l}112 \pm 40^{e} \\
n=18\end{array}$ & $\begin{array}{l}1120 \pm 64^{\mathrm{c}, \mathrm{e}} \\
\mathrm{n}=37 \\
8900^{\mathrm{D}} \mathrm{kg}\end{array}$ & $\begin{array}{l}<10^{\mathrm{e}} \\
\mathrm{n}=37\end{array}$ & $\begin{array}{l}28 \pm 3^{\mathrm{e}} \\
\mathrm{n}=37 \\
218 \mathrm{~kg}\end{array}$ & $\begin{array}{l}19.4 \pm 0.7^{\mathrm{e}} \\
\mathrm{n}=32 \\
140,000 \mathrm{~kg}\end{array}$ \\
\hline Groundwater inflow & $\begin{array}{l}257.2 \pm 20.1^{\mathrm{b}} \\
\mathrm{n}=4\end{array}$ & & $\begin{array}{l}89 \pm 56^{\mathrm{e}} \\
\mathrm{n}=6 \\
\left(<10-100^{\mathrm{a}}\right) \\
23 \mathrm{~kg}\end{array}$ & & $\begin{array}{l}86 \pm 56^{\mathrm{e}} \\
\mathrm{n}=6 \\
\left(<1-4^{\mathrm{a}}\right) \\
22 \mathrm{~kg}\end{array}$ & & $\begin{array}{l}\quad 8.2 \pm 1.7^{\mathrm{e}} \\
\mathrm{n}=6 \\
2100 \mathrm{~kg}\end{array}$ \\
\hline River outflow & $\begin{array}{l}7922 \pm 2727^{\mathrm{b}} \\
\mathrm{n}=4\end{array}$ & $\begin{array}{l}55 \pm 10^{\mathrm{e}} \\
\mathrm{n}=18\end{array}$ & $\begin{array}{l}351 \pm 31^{\mathrm{e}} \\
\mathrm{n}=19\end{array}$ & $\begin{array}{l}\quad 612 \pm 34^{\mathrm{c}, \mathrm{e}} \\
\mathrm{n}=43 \\
7628^{\mathrm{D}} \mathrm{kg}\end{array}$ & $\begin{array}{l}<10^{\mathrm{e}} \\
\mathrm{n}=43\end{array}$ & $\begin{array}{l}14 \pm 3^{\mathrm{e}} \\
\mathrm{n}=43 \\
79 \mathrm{~kg}\end{array}$ & $\begin{array}{l}\quad 7.9 \pm 0.5^{\mathrm{e}} \\
\mathrm{n}=41 \\
62600 \mathrm{~kg}\end{array}$ \\
\hline Groundwater outflow & $\begin{array}{l}289.2 \pm 33.7^{\mathrm{b}} \\
\mathrm{n}=4\end{array}$ & $\begin{array}{l}34.1 \pm 6.0 \\
\mathrm{n}=17 \\
10 \mathrm{~kg}\end{array}$ & $\begin{array}{l}373 \pm 51^{\mathrm{e}} \\
\mathrm{n}=17 \\
108 \mathrm{~kg}\end{array}$ & & $\begin{array}{l}2.9 \pm 0.7^{\mathrm{e}} \\
\mathrm{n}=17 \\
0.8 \mathrm{~kg}\end{array}$ & & $\begin{array}{l}13.1 \pm 5.1^{\mathrm{e}} \\
\mathrm{n}=11 \\
3800 \mathrm{~kg}\end{array}$ \\
\hline Total inflows & & & & $9281^{\mathrm{f}} \mathrm{kg}$ & & $261^{\mathrm{f}} \mathrm{kg}$ & $142.2 \mathrm{t}$ \\
\hline Total outflows & & & & $7746^{\mathrm{f}} \mathrm{kg}$ & & $80^{\mathrm{f}} \mathrm{kg}$ & $66.4 \mathrm{t}$ \\
\hline
\end{tabular}

${ }^{\text {a }}$ Data from Salmon et al. (2008)

${ }^{\mathrm{b}}$ Data from Lund et al. (2018)

${ }^{\mathrm{c}}$ Measured as total Kjeldahl $\mathrm{N}$

${ }^{\mathrm{d}}$ Includes load estimates from $\mathrm{NO}_{3} / \mathrm{NO}_{2}$ and total Kjeldahl $\mathrm{N}$ to be equivalent to Total $\mathrm{N}$

${ }^{\mathrm{e}}$ Data from Premier Coal, unpublished

${ }^{\mathrm{f}}$ Includes dissolved nutrients for groundwater

${ }^{\mathrm{g}}$ Data from Khwanboonbumpen (2006)

the lakes with water depth, except in 2018 in Kepwari (Supplemental Table 4). The most noticeable change in percent organic matter with depth occurred in the shallow depths with large increases between 2016 and 2018 in both lakes (Supplementary Table 4).

Most of the sedimentation in the centre of both WO5H and Kepwari was derived from non-carbon sources; however, there were few consistent spatial patterns in the data (Fig. 5). In 2016, across both lakes and depths, the average percent total carbon retrieved from traps was $8.8 \pm 1.3 \%$, increasing to $32.2 \pm 2.7 \%$ in 2017 and $16.2 \pm 1.8 \%$ in 2018 . Although total sedimentation rates did vary among depths, there was no consistent trend within or between lakes. Therefore, the highest mean rates of total deposition, across all depths, occurred in 2016 in Kepwari $\left(4.7 \pm 0.8 \mathrm{~g} \mathrm{~m}^{-2}\right.$ day $\left.^{-1}\right)$; these was substantially lower in 2017 and $2018\left(1.9 \pm 0.8 \mathrm{~g} \mathrm{~m}^{-2}\right.$ day $^{-1}$ and $0.9 \pm 0.2 \mathrm{~g} \mathrm{~m}^{-2} \mathrm{day}^{-1}$, respectively; Fig. 5). There was also a spike in total sedimentation in Lake Kepwari at $40 \mathrm{~m}$ depth in $2017\left(6 \mathrm{~g} \mathrm{~m}^{-2} \mathrm{day}^{-1}\right)$. Overall carbon sedimentation rates were highest in 2017 at $0.6 \pm 0.2 \mathrm{~g} \mathrm{~m}^{-2} \mathrm{day}^{-1}$, followed by 2016 at $0.4 \pm 0.04 \mathrm{~g} \mathrm{~m}^{-2} \mathrm{day}^{-1}$, and lowest in 2018 at $0.1 \pm 0.02 \mathrm{~g} \mathrm{~m}^{-2} \mathrm{day}^{-1}$.

In 2016, there was $94 \mathrm{~mm}$ (daily maximum of $11.8 \mathrm{~mm}$ ) of rainfall, in 2017, $104.8 \mathrm{~mm}(\max .34 \mathrm{~mm})$ and in 2018, $44.4 \mathrm{~mm}$ (max. $17.6 \mathrm{~mm}$ ) during sampling. Additionally, during the deployment of the samplers, average flows at the Premier Coal gauging station just downstream of Lake Kepwari were 84.5 ML, 21.6 ML, and 15.5 ML for 2016-2018, respectively (unpublished data from the Dept. of Water and Environmental Regulation, Western Australia). High river in-flows appeared to be responsible for the high sedimentation rates in 2016, rather than localised runoff from the immediate catchment surrounding the lake due to rain events.

At the edges of WO5H and Kepwari in 2018, total sedimentation rate $\left(\mathrm{F}_{1,4}=0.034, \mathrm{P}=0.863\right)$ and carbon sedimentation rates $\left(\mathrm{F}_{1,4}=0.148, \mathrm{P}=0.720\right)$ were not significantly different between lakes. Sedimentation rates (total and carbon) were very similar between the edge and $10 \mathrm{~m}$ deep centre samples in both lakes in 2018. 
Fig. 5 Pelagic sedimentation rate in the centre of Lakes WO5H and Kepwari in September/October of 2016, 2017 and 2018. Data are shown as mean (of triplicate evaluation units, no standard error) showing both carbon and non-carbon content at three water depths $(10,25$, $40 \mathrm{~m})$

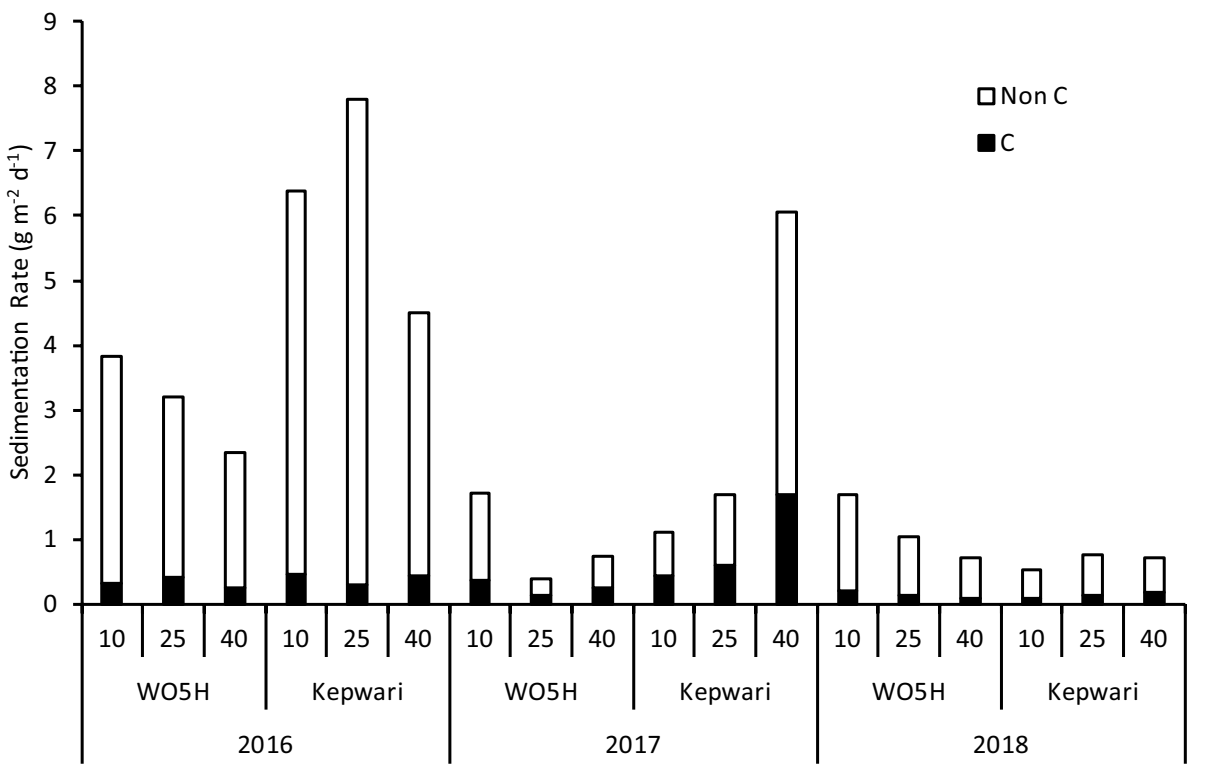

\section{Stage 3: A Simple Nutrient Budget for Kepwari}

In 2013-2016, the CRSB accounted for $87 \%$ of the water entering Lake Kepwari, with direct rainfall accounting for $9 \%$, groundwater 3\%, and surface runoff (from the local catchment) $1 \%$. Evaporation was the largest loss term for the water budget (see Lund and Blanchette 2018), and was not considered further as it is unlikely to be a significant loss pathway for nutrients. River outflow was marginally larger than river inflow while groundwater outflow and inflow were similar (Table 4).

Direct rainfall had the lowest estimated nutrient concentrations of the water inputs, with surface runoff having the highest concentrations of total $\mathrm{P}$ and $\mathrm{N}$, but low dissolved nutrients (except ammonia) and low total organic C (TOC) (Table 4). Groundwater inflows had the highest concentrations of filterable reactive phosphorus (FRP) compared to other inflows. However, the large volumes of CRSB inflows resulted in $8.9 \mathrm{t}$ of total N, $218 \mathrm{~kg}$ of total P, and $140 \mathrm{t}$ of TOC, which dwarfed the contributions from the other inflows (Table 4). Export rates for the CRSB catchment upstream of Lake Kepwari were $234.2 \mathrm{~kg} \mathrm{~km}^{-2}$ year $^{-1}$ for TOC, $0.36 \mathrm{~kg} \mathrm{~km}^{-2}$ year $^{-1}$ for total $\mathrm{P}$, and $14.8 \mathrm{~kg} \mathrm{~km}^{-2}$ year $^{-1}$ for total $\mathrm{N}$, while surface runoff had much lower export rates of $70.6 \mathrm{~kg} \mathrm{~km}^{-2}$ year $^{-1}$ for TOC, but higher rates of $8.7 \mathrm{~kg} \mathrm{~km}^{-2}$ year ${ }^{-1}$ for total $\mathrm{P}$ and $57.1 \mathrm{~kg} \mathrm{~km}^{-2}$ year $^{-1}$ for total $\mathrm{N}$.

River outflow removed not only river-derived nutrients but also those from surface runoff, direct rainfall, and groundwater removing approximately $62.6 \mathrm{t}$ of TOC, $79 \mathrm{~kg}$ of total $\mathrm{P}$, and 7.6 $\mathrm{t}$ of total $\mathrm{N}$ per annum. Groundwater was estimated to remove a further $3.8 \mathrm{t}$ of TOC, $0.8 \mathrm{~kg}$ of P (as FRP), and $118 \mathrm{~kg}$ of N (as $\mathrm{NH}_{3}$ and $\mathrm{NO}_{3} / \mathrm{NO}_{2}$ ). Despite losses from the lake, it is likely that $1,535 \mathrm{~kg}$ of N, $181 \mathrm{~kg}$ of P, and $75.8 \mathrm{t}$ of TOC were being stored or utilized in the lake in an average 2013-2018 year.

\section{Discussion}

Allochthonous input underpins passive ecosystem development in pit lakes and is a key aspect of catchment rehabilitation and mine closure. Therefore, the broad aim of this research was to determine if catchment characteristics were related to pit lake nutrient concentrations. We hypothesised that: (1) catchment characteristics would vary among pit lakes, (2) pit lake catchments would be different from cooccurring naturally-forested catchments, and (3) connection of a pit lake to a naturally-forested catchment would increase $\mathrm{C}$ accumulation in the pit lakes.

In research stage 1, we found that catchment vegetation was significantly different among pit lakes, which was driven mainly by variables associated with WON9, the youngest catchment. However, vegetation was similar among pit-lake catchments in that that there were no true riparian tree species at the edges. Older pit lake catchments had similar tree densities and basal areas to old-growth jarrah forests, whereas younger catchments more closely resembled jarrah regrowth forests and nearby rehabilitated bauxite mines in terms of tree stocking (Grigg and Grant 2009; McCaw 2011). The differences among catchment vegetation did not translate to soils; there was no significant difference in soil physico-chemistry among catchments, although soils were different between 'edge' and 'upslope' areas. Soil concentrations of $\mathrm{C}$ and $\mathrm{P}$ (5-10 m out from shore) among catchments and nutrients were higher in upslope soils compared to edges. The nutrient levels ( $\mathrm{N} \& \mathrm{P}), \mathrm{pH}$, organic carbon, and $\mathrm{EC}$ of studied 
catchments were however broadly in line with those typically found in mature, undisturbed native jarrah forest (Hingston and Jones 1985; McCaw 2011; Morley et al. 2004).

In research stage 1, we also found that pit lake catchments were generally similar to natural forest, although the vegetation in pit lake catchments was younger, resulting in less biomass and leaf litter. In both pit-lake and naturally-forested catchments, leaf litter was higher upslope than compared to edge locations. There was a positive relationship for soil organic carbon and leaf litter but no other measured nutrients.

In research stage 2, we investigated sedimentation in two pit lakes - one connected to a river (Kepwari) and one not connected to the wider catchment (WO5H). Pit lakes had relatively small catchments compared to their surface areas except when connected to watercourses. We hypothesised that Kepwari would have higher levels of carbon and sedimentation than WO5H because hydrological connection to a large, naturallyforested catchment would facilitate delivery of organic materials to the lake. However, we found that sediment organic matter content and sedimentation were not significantly different. Sediment depth and collection year were both significant factors, with both lakes exhibiting the same pattern in the data; percent organic matter (\% OM) tended to increase with depth, and the greatest temporal increase in \% OM occurred in shallow waters $(<10 \mathrm{~m})$. The composition of deep-water pelagic sediments was similar between WO5H and Kepwari, with most being non-carbon, but there were few consistent spatial or temporal patterns in the central sedimentation data between lakes. There was also no significant difference in sedimentation rate (total and $\mathrm{C}$ ) between lakes around the edges. Thus, the hypothesis that connecting a pit lake to a watercourse would increase carbon concentrations and sedimentation was not supported.

Leaf litter cover in pit lake catchments and co-occurring unmined forests was similar. However, only small quantities of organic matter were found within $10 \mathrm{~m}$ of the shoreline and there was no significant difference in percent organic matter by sediment depth near the shore. These results indicate uniform rates of organic matter deposition. While we did not distinguish between allochthonous and autochthonous materials in our research, the apparent lack of $\mathrm{C}$ in the lake sediments was consistent with previously published studies describing the low mobility of upland vegetation. One study found that only about $7 \%$ of the allochthonous C entering a stream was from upland sources and riparian vegetation provided the remainder (Dosskey and Bertsch 1994). In our research, pit lakes did not have riparian tree species, which likely hindered allochthonous input.

We hypothesised that connecting a pit lake to a river would encourage the growth of riparian tree species because this process had been demonstrated in other artificial lakes (see Mitsch et al. 2012). After 60 years, a riparian zone was not present in Stockton despite inflows from EW1. Similarly, in $\mathrm{WO} 5 \mathrm{H}$ and Kepwari the absence of riparian vegetation suggested that interventions might be required to develop a riparian community. Riparian species are unlikely to succeed if planted at the same time as upland species as it may take many years for the lake to fill; the riparian community is unlikely to cope with the rapid changes in water level (van Etten 2011). Plantings of riparian species should occur post-filling to enhance the development of this potentially important source of allochthonous C.

Although connection to a watercourse did not appear to promote the establishment of riparian vegetation, we did observe the growth of submerged plants (predominantly Chara spp.) in Lake Kepwari after river inflows in 2013, which were not observed in the lake prior to river connection (pers. obs.). River inflow changed the water quality of the lake from broadly acidic to circumneutral, particularly in the shallows (see Lund and Blanchette 2018), creating more favourable conditions for Chara growth in the pit lake (see Pietsch 1998). The presence of decaying Chara in the sediments was likely to have contributed to observed nutrient levels. In addition to the Chara, we observed thick organic 'growth' on the benthos of Lake Kepwari (Fig. 6). We previously described the benthic microbes associated with Lakes Kepwari and WO5H and found that assemblages were significantly different between lakes, although many taxa could not be identified beyond class (Blanchette et al. 2019). We did not specifically target the organic 'growth' for identification in Kepwari, although it was likely incorporated in samples along with other taxa. Future work should include determining the ratio of allochthonous to autochthonous materials using stable isotopes and more targeted sampling.

We hypothesised that connection to a watercourse would increase sediment carbon concentration in pit lakes but found that Kepwari and WO5H had similar \% C content in the sediments. These results could be due in part to the autochthonous sources

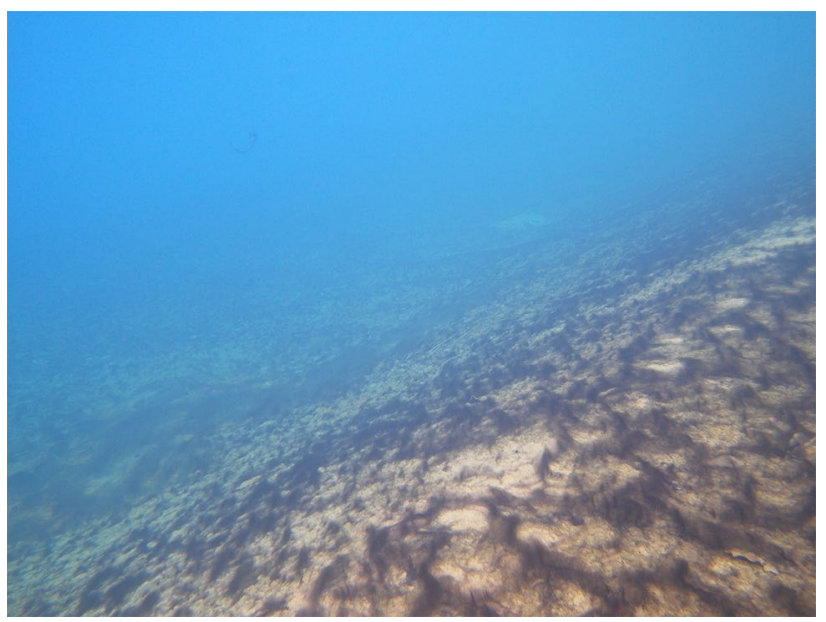

Fig. 6 Unidentified organic 'growth' on the benthos of Lake Kepwari in April 2013 
in Lake Kepwari (as above), or the methodology we employed. Broad differences in lake bathymetry was unlikely to have played a role given that $\% \mathrm{C}$ content in sediments was not significantly different between lakes. Sediments in WO5H contained coal fines, which were removed when possible, although they may have increased the $\% \mathrm{C}$ in the sediment samples. The sediment collection methodology homogenised at least the top $100 \mathrm{~mm}$, effectively diluting organic accumulation since river inflow, which may explain why no significant difference was found between lakes. Additionally, our measure of $\% \mathrm{C}$ may have been too broad; future research could identify carbon sources and lability using the 'multiple-lines-of-evidence' approach of Laskov et al. (2002).

The addition of a river to Lake Kepwari substantially increased catchment size but did not result in significant differences in nutrient concentrations compared to the unconnected Lake WO5H. As above, it is possible that our methods did not detect nutrient source or type. Another potential explanation is that the complex hydrological dynamics related to (1) a river flowing through a lake and (2) the large volume of the lake, resulted in no detectible increase in pelagic and benthic nutrients during the experimental time frame. While nutrients flowed into the lake via the river with the lake acting as a net nutrient 'sink,' there was also a large quantity of nutrients flowing out of the lake, indicating that the very nature of the flow-through, while delivering nutrients, was actually exporting nutrients at the same time.

The water balance and nutrient model suggests that most (87\%) of the water that entered the lake was from the river, and that river outflow was slightly larger than river inflow. Despite the fact that surface runoff from the local catchment contributed only $1 \%$ of the overall water input, it had the highest concentrations of $\mathrm{P}$ and N, though not TOC. Groundwater inflows had the highest concentrations of FRP. Although the river had lower concentrations of nutrients than other sources, the large volumes of water carried a larger total volume of nutrients, resulted in the river being the most important contributor of $\mathrm{P}, \mathrm{N}$, and C. River outflow was slightly higher than river inflow, and nutrients were removed from the lake with the river outflows. However, the model suggests that the lake did act like a nutrient sink, with more $\mathrm{N}, \mathrm{P}$, and TOC in the inflows than the outflow.

The low concentration of calculated TOC in surface runoff at Lake Kepwari may have been due to the young age of the vegetation at the time of data collection in 2004, at which point the revegetated catchment was $\approx 8$ years old. However, the surface runoff TOC data should be used with caution, as it came from only one sample and may not have reflected average catchment runoff. At the time of our study beginning in 2012, the vegetation at Lake Kepwari more closely resembled native forest in terms of biomass and litter (Abbott and Loneragan 1986; McCaw 2011; Stoneman et al. 1997), suggesting that TOC export may have increased. Then again, a lack of riparian vegetation may be more important to TOC export rates than upland vegetation. Further research is required to not only expand and update TOC catchment export but determine the importance of riparian vegetation to TOC runoff in pit lakes.

\section{Conclusions}

We found that it took 10-15 years of growth for actively rehabilitated pit lake catchments and up to 60 years for unrehabilitated pit lake catchments to approximate natural forest in terms of soil physio-chemistry, tree density, and leaf litter accumulation. Active rehabilitation, rather than a 'lock and leave' approach, leads to better outcomes for pit lake catchment vegetation. However, pit lake catchments are typically one tenth (or less) the size of natural lake systems. Therefore, despite the relatively good production of upslope litter, the total quantity available for transport to the lake is similarly reduced. Additionally, lack of a riparian zone appeared to be the single most important factor limiting allochthonous inputs of organic matter into the pit lakes. Leaf litter levels were low in the terrestrial areas close to the lakes' edges, which translated into low levels of organic matter content in lake sediments at the edge. The importance of the riparian zone to aquatic ecosystem function has been well-documented (Naiman and Decamps 1997), and their importance to mine pit lakes are no exception (van Etten 2011).

The Collie River flowing through Lake Kepwari substantially increased catchment size and large amounts of riverderived carbon were deposited in the lake. However, carbon concentrations were relatively low compared to the size of the lake and were only detected in the littoral sediments, which may have resulted from autochthonous production. Connecting pit lakes to natural waterways has the advantage of potentially introducing a range of propagules that could stimulate the development of riparian communities, but this was not readily evident at Kepwari during the experiment. Results of this study suggest that the quantity of organic C required for large pit lakes to ecologically approach natural lakes is prohibitive, and even connection to substantial catchments does not result in a 'quick fix.' Although pit lakes can be considered 'new lakes', subject to the same ecological principles as naturally-formed lakes (see Blanchette and Lund 2016), active interventions are required if stakeholders are unwilling to wait decades for the biological development of pit lakes as part of closure planning.

Acknowledgements This study was jointly funded by Australian Coal Association Research Program (Projects C21038, C23025), Edith Cowan University, and Premier Coal Ltd. We thank Premier Coal Ltd (C. Harkin, E. Evans, J. Edwards) and the Dept. of Environment and Conservation (now Biodiversity, Conservation and Attractions) for access to the lakes and logistic support. Thanks to the staff and students at Edith Cowan University, primarily M. Bannister for chemical analysis, and C. McCullough, R. Bignell, N. Greaves, T. Charles, C. 
Guo, M. Newport, and J. Gonzalez Pinto who all contributed to the field work. Access to Lake Kepwari was kindly provided by D. Graham. We also thank the people of Collie, WA.

Open Access This article is licensed under a Creative Commons Attribution 4.0 International License, which permits use, sharing, adaptation, distribution and reproduction in any medium or format, as long as you give appropriate credit to the original author(s) and the source, provide a link to the Creative Commons licence, and indicate if changes were made. The images or other third party material in this article are included in the article's Creative Commons licence, unless indicated otherwise in a credit line to the material. If material is not included in the article's Creative Commons licence and your intended use is not permitted by statutory regulation or exceeds the permitted use, you will need to obtain permission directly from the copyright holder. To view a copy of this licence, visit http://creativecommons.org/licenses/by/4.0/.

\section{References}

Abbott I, Loneragan OW (1986) Ecology of Jarrah (Eucalyptus marginata) in the northern Jarrah forest of Western Australia. In: Western Australian Dept of Conservation and Land Management, Perth

APHA (2017) Standard methods for the examination of water and wastewater. 23rd edn. American Public Health Assoc, American Water Works Assoc, Water Environment Federation, Washington DC

Banks D, Younger PL, Arnesen R-T, Iversen ER, Banks SB (1997) Mine-water chemistry: the good, the bad and the ugly. Environ Geol 32(3):157-174

Benfield EF (2007) Decomposition of leaf material. In: Hauer FR, Lamberti GA (eds) Methods in Stream ecology. Academic Press, Amsterdam, pp 711-720

Blanchette ML, Lund MA (2016) Pit lakes are a global legacy of mining: an integrated approach to achieving sustainable ecosystems and value for communities. Curr Opin Env Sust 23:28-34

Blanchette ML, Allcock R, Gonzalez J, Kresoje N, Lund M (2019) Macroinvertebrates and microbes (archaea, bacteria) offer complementary insights into mine-pit lake ecology. Mine Water Environ. https://doi.org/10.1007/s10230-019-00647-9

Blattmann TM, Wessels M, McIntyre CP, Eglinton TI (2019) Petrogenic organic carbon retention in terrestrial basins: a case study from perialpine Lake Constance. Chem Geol 503:52-60. https:// doi.org/10.1016/j.chemgeo.2018.10.021

Blodau C (2006) A review of acidity generation and consumption in acidic coal mine lakes and their watersheds. Sci Total Environ 369(1):307-332. https://doi.org/10.1016/j.scitotenv.2006.05.004

Bloesch J, Burns NM (1980) A critical review of sedimentation trap technique. Schweiz Z Hydrol 42(1):15-55

Campbell RS, Lind OT (1969) Water quality and aging of strip mine lakes. J Water Pollut Con F 41:1943-1955

Clarke KR, Gorley RN (2015) PRIMER v7: user manual. PRIMER-E, Plymouth

Cramer VA, Hobbs RJ (2002) Ecological consequences of altered hydrological regimes in fragmented ecosystems in southern Australia: impacts and possible management responses. Austral Ecol 27(5):546-564. https://doi.org/10.1046/j.1442-9993.2002.01215.x

Dosskey MG, Bertsch PM (1994) Forest sources and pathways of organic matter transport to a blackwater stream: a hydrologic approach. Biogeochemistry 24(1):1-19. https://doi.org/10.1007/ BF00001304

Fyson A, Nixdorf B, Kalin M, Steinberg CEW (1998) Mesocosm studies to assess acidity removal from acidic mine lakes through controlled eutrophication. Ecol Eng 10:229-245
Fyson A, Nixdorf B, Kalin M (2006) The acidic lignite pit lakes of Germany-microcosm experiments on acidity removal through controlled eutrophication. Ecol Eng 28:288-295

Geller W, Schultze M (2013a) Biological in-lake treatment. In: Geller W, Schultze M, Kleinmann R, Wolkersdorfer C (eds) Acidic pit lakes: the legacy of coal and metal surface mines. Springer-Verlag, Berlin, pp 236-240

Geller W, Schultze M (2013b) Hydrological management and chemical in-lake treatments. In: Geller W, Schultze M, Kleinmann R, Wolkersdorfer C (eds) Acidic pit lakes: the legacy of coal and metal surface mines. Springer, Berlin, pp 228-236

Grigg AH (2017) Hydrological response to bauxite mining and rehabilitation in the jarrah forest in south west Australia. J Hydrol Reg Stud 12:150-164. https://doi.org/10.1016/j.ejrh.2017.05.008

Grigg AH, Grant C (2009) Overstorey growth response to thinning, burning and fertiliser in 10-13-year-old rehabilitated jarrah (Eucalyptus marginata) forest after bauxite mining in southwestern Australia. Aust Forestry 72(2):80-86

Harper RJ, Smettem KRJ, Tomlinson RJ (2005) Using soil and climatic data to estimate the performance of trees, carbon sequestration and recharge potential at the catchment scale. Aust J Exp Agr 45:1389-1401

Hingston F, Jones M (1985) Changes in the composition of soil solutions resulting from application of fertilizer to jarrah forest in south-western Australia. Aust Forest Res 15:293-308

Hulbert SH (1984) Pseudoreplication and the design of ecological field experiments. Ecol Monogr 54(2):187-211

Johnson DW, Turner J (2019) Nutrient cycling in forests: a historical look and newer developments. Forest Ecol Manag 444:344-373. https://doi.org/10.1016/j.foreco.2019.04.052

Jones PE, Consuegra S, Börger L, Jones J, Garcia de Leaniz C (2020) Impacts of artificial barriers on the connectivity and dispersal of vascular macrophytes in rivers: a critical review. Freshw Biol 65(6):1165-1180

Kalin M, Geller W (1998) Limnological fundamentals of acid mining lakes. In: Geller W, Klapper H, Salomons W (eds) Acidic Mining lakes. Springer, Berlin, pp 423-425

Kent M (2011) Vegetation description and data analysis: a practical approach. Wiley, Oxford

Khwanboonbumpen S (2006) Sources of nitrogen and phosphorus in stormwater drainage from established residential areas and options for improved management. PhD Diss, Edith Cowan Univ. https://ro.ecu.edu.au/theses/75

King DL, Simmler JJ, Decker CS, Ogg CW (1974) Acid strip mine lake recovery. J Water Pollut Con F 46:2301-2315

Kopácek J, Hejzlar J, Borovec J, Porcal P, Kotorová I (2000) Phosphorus inactivation by aluminum in the water column and sediments: lowering of in-lake phosphorus availability in an acidified watershed-lake ecosystem. Limnol Oceanogr 45(1):212-225

Kumar RN, McCullough CD, Lund MA, Larranaga SA (2016) Assessment of factors limiting algal growth in acidic pit lakes-a case study from Western Australia, Australia. Environ Sci Pollut R 23(6):5915-5924. https://doi.org/10.1007/s11356-015-5829-0

Laskov C, Amelung W, Peiffer S (2002) Organic matter preservation in the sediment of an acidic mining lake. Environ Sci Tech 36(20):4218-4223

Lund MA, Blanchette ML (2018) C23025 Coal pit lake closure by river flow through: risks and opportunities, Report № 2018-3 to the Australian Coal Assoc Research Program. Edith Cowan Univ, Perth

Lund MA, McCullough C (2008) Limnology and ecology of low sulphate, poorly-buffered, acidic coal pit lakes in Collie, Western Australia. In: Rapantova N, Hrkal Z (eds), Proc, 10th Intern Mine Water Assoc Congr. Technical Univ of Ostrava, Ostrava, Czech Republic, pp 591-594 
Lund MA, McCullough CD (2009) Biological remediation of low sulphate acidic pit lake waters with limestone $\mathrm{pH}$ neutralisation and amended nutrients. In: Proc, 11th Intern Mine Water Assoc Conf, Pretoria, pp 519-525

Lund MA, McCullough CD (2011) Meeting environmental goals for pit lake restoration: factoring in the Biology. In: McCullough CD (ed) Mine pit lakes: closure and management. Australian Centre for Geomechanics, Perth, pp 83-90

Lund MA, McCullough CD (2015) Addition of bulk organic matter to acidic pit lakes may facilitate closure. In: Brown A, Bucknam C, Burgess J et al. (eds) Proc, 10th ICARD/int mine water assoc conf: agreeing on solutions for more sustainable mine water management. Sanitago, Chile, paper 52

Lund MA, McCullough CD, Kumar RN (2012) The Collie Pit Lake District, Western Australia: An Overview. In: McCullough C, Lund M, Wyse, L (eds) Proc, int mine water assoc, Bunbury, Australia, pp 287-294

Lund MA, Blanchette ML, McCullough CD (2014) C21038 enhancing ecological values of coal pit lakes with simple nutrient additions and bankside vegetation, report № 2014-3 to the Australian Coal Assoc Research Program, Mine Water and Environment Research/ Centre for Ecosystem Management, Edith Cowan Univ, Perth, Western Australia

Lund MA, Blanchette ML, Harkin C (2018) Seasonal river flowthrough as a pit lake closure strategy: is it a sustainable option in a drying climate? In: Wolkersdorfer C, Sartz L, Weber A, Burgess J, Tremblay G (eds), Proc, 11th ICARD \& IMWA annual conf: mine water-risk to opportunity, vol I. Tshwane Univ of Technology, Pretoria, pp 34-41

Lund MA, Polifka J, Quintero Vasquez M, Ramesseur R, Bignell R, Yangzom D (2019) Sedimentation rates in two pit lakes: implications for riverine flow-through as a closure strategy. In: Wolkersdorfer C, Khayrulina E, Polyakova S, Bogush A (eds) Proc, int mine water assoc: mine water: technological and ecological challenges. Perm State University, Perm, pp 477-484

Lymbery AJ, Doupé RG, Pettit NE (2003) Effects of salinisation on riparian plant communities in experimental catchments on the Collie River, Western Australia. Aust J Bot 51(6):667-672. https ://doi.org/10.1071/BT02119

McCaw WL (2011) Characteristics of jarrah (Eucalyptus marginata) forest at FORESTCHECK monitoring sites in south-west Western Australia: stand structure, litter, woody debris, soil and foliar nutrients. Austral For 74:254-265

McCullough CD, Schultze M (2018) Engineered river flow-through to improve mine pit lake and river values. Sci Total Environ 640-641:217-231. https://doi.org/10.1016/j.scitotenv.2018.05.279

McCullough CD, Lund MA, May JM (2008) Field scale trials treating acidity in coal pit lakes using sewage and green waste. In: Rapantova N, Hrkal Z (eds) Proc, 10th Int Mine Water Assoc Congr, Technical Univ of Ostrava, Czech Republic, p 599-602

McCullough CD, Lund M, Zhao L (2009) Mine voids management strategy (I): pit lake resources of the Collie Basin. In: MiWER/ Centre for Ecosystem Management Report 2009-10 to the Dept of Water. Edith Cowan Univ, Perth

McCullough CD, Kumar RN, Lund MA, Newport M, Ballot E, Short D (2012) Riverine breach and subsequent decant of an acidic pit lake: evaluating the effects of riverine flow-through on lake stratification and chemistry. In: McCullough C, Lund M, Wyse L (eds) Proc. Int Mine Water Assoc, Bunbury, pp 533-539

Mitsch WJ, Zhang L, Stefanik KC, Nahlik AM, Anderson CJ, Bernal B, Hernandez M, Song K (2012) Creating wetlands: primary succession, water quality changes, and self-design over 15 years. Bioscience 62:237-250. https://doi.org/10.1525/bio.2012.62.3.5

Moncrieff JS (1993) Hydrogeology of the Collie Basin, Western Australia: Western Australia Geological Survey, Report № 34, pp $129-153$
Moody W (2017) Overview of Western Australia's coal industry. Energy News 35(1):14-16

Morley S, Grant C, Hobbs R, Cramer V (2004) Long-term impact of prescribed burning on the nutrient status and fuel loads of rehabilitated bauxite mines in Western Australia. Forest Ecol Manag 190(2-3):227-239

Müller M, Eulitz K, McCullough C, Lund M (2010) Mine voids management strategy $(\mathrm{V})$ : water quality modelling of Collie Basin Pit Lakes. MiWER/Centre for Ecosystem Management Report 2010-10 to the Department of Water. Edith Cowan Univ, Perth

Naiman RJ, Decamps H (1997) The ecology of interfaces: riparian zones. Ann Rev Ecol Syst 28(1):621-658

Opitz J, Alte M, Bauer M, Schäfer W, Söll T (2017) Investigation of a pit lake acting as a large-scale natural treatment system for diffuse acid mine drainage. In: Wolkersdorfer C, Sartz L, Sillanpää M, Häkkinen A (eds) Proc, 13th Intern Mine Water Assoc Congr: Mine Water \& Circular Ecomomy, vol II. Lappeenranta Univ of Technology, Lappeenranta, pp 1095-1102

Perera KC, Western AW, Nawarathna B, George B (2015) Comparison of hourly and daily reference crop evapotranspiration equations across seasons and climate zones in Australia. Agr Water Manage 148:84-96. https://doi.org/10.1016/j.agwat.2014.09.016

Phillips B, Evans L, Sappal K, Fox J, John J, Lund M (2000) Final void water quality enhancement, report № C8031, Australian Coal Assoc Research Program. Curtin Univ, Perth

Pietsch W (1998) Colonization and development of vegetation in mining lakes of the Lusatian lignite area depending on water genesis. In: Geller W, Klapper H, Salomons W (eds) Acidic mining lakes. Springer, Berlin, pp 169-193

Platt J, Tingey W, Sparks TC (2012) Collie River salinity recoveryimproving water resource outcomes in a competing environment. In: Proc, 15th Intl River Symp, Melbourne

Preuss V, Horn M, Koschorreck M, Luther G, Wendt-Potthoff K, Geller W (2007) In-lake bioreactors for the treatment of acid mine water in pit lakes. Adv Mat Res 20-21:271-274. https://doi.org/10.4028/ www.scientific.net/AMR.20-21.271

Pribyl DW (2010) A critical review of the conventional SOC to SOM conversion factor. Geoderma 156(3-4):75-83. https://doi. org/10.1016/j.geoderma.2010.02.003

Rayment GE, Higginson FR (1992) Australian laboratory handbook of soil and water chemical methods. Inkata Press, Melbourne

Salmon SU, Oldham CE, Ivey GN (2008) Assessing internal and external controls on lake water quality: limitations on organic carbondriven alkalinity generation in acidic pit lakes. Water Resour Res 44:10. https://doi.org/10.1029/2007wr005959

Sepp M, Kõiv T, Nõges P, Nõges T (2019) The role of catchment soils and land cover on dissolved organic matter (DOM) properties in temperate lakes. J Hydrol 570:281-291. https://doi.org/10.1016/j. jhydrol.2019.01.012

Sienkiewicz E, Gąsiorowski M (2016) The evolution of a mining lake-from acidity to natural neutralization. Sci Total Environ 557-558:343-354. https://doi.org/10.1016/j.scitotenv.2016.03.088

Stedman C (1988) 100 years of collie coal. Curtin Printing Services, Perth

Stoneman GL, Crombie DS, Whitford K, Hingston FJ, Giles R, Portlock CC, Galbraith JH, Dimmock GM (1997) Growth and water relations of Eucalyptus marginata (Jarrah) stands in response to thinning and fertilization. Tree Physiol 17:267-274

Toming K, Tuvikene L, Vilbaste S, Agasild H, Viik M, Kisand A, Feldmann T, Martma T, Jones RI, Noges T (2013) Contributions of autochthonous and allochthonous sources to dissolved organic matter in a large, shallow, eutrophic lake with a highly calcareous catchment. Limnol Oceanogr 58(4):1259-1270. https://doi. org/10.4319/lo.2013.58.4.1259

Tucci NJ, Gammons CH (2015) Influence of copper recovery on the water quality of the acidic Berkeley Pit Lake. Montana, USA 
Envir Sci Tech 49(7):4081-4088. https://doi.org/10.1021/es504 916n

van Etten EJB (2011) The role and value of riparian vegetation for mine pit lakes. In: McCullough CD (ed) Mine pit lakes: Closure And Management. Australian Centre for Geomechanics, Perth, pp 91-106

Verstraeten G, Poesen J (2000) Estimating trap efficiency of small reservoirs and ponds: methods and implications for the assessment of sediment yield. Prog Phys Geog 24(2):219-251. https://doi. org/10.1177/030913330002400204

Wetzel RG (2003) Limnology, 3rd edn. W.B. Saunders Co, Philadelphia

Woelfl S, Zippel B, Kringel R (2000) Occurrence of an algal mass development in an acidic ( $\mathrm{pH} 25)$, iron and aluminium-rich coal mining pond. Acta Hydroch Hydrob 28(6):305-309
Zhao LYL, McCullough CD, Lund MA (2009) Pit Lake Resources of the Collie Basin, Centre for Ecosystem Management, Mine Water and Environment Research Centre, Edith Cowan Univ, Perth

Publisher's Note Springer Nature remains neutral with regard to jurisdictional claims in published maps and institutional affiliations. 